\title{
Exploring the global animal biodiversity in the search for new drugs -Amphibians
}

\author{
Dennis RA Mans*, Jennifer Pawirodihardjo, Meryll Djotaroeno and Priscilla Friperson \\ Department of Pharmacology, Faculty of Medical Sciences, Anton de Kom University of Suriname, Paramaribo, Suriname
}

\begin{abstract}
Many breakthrough drugs have been developed from plants with medicinal properties on the basis of ethnopharmacological information. In the search for structurally novel and mechanistically unique lead compounds, drug discovery and development progams are now also paying attention to the myriad of bioactive molecules provided by the animal biodiversity. A well-known example emerging from these efforts is the breakthrough angiotensin-converting enzyme inhibitor captopril used for the treatment of hypertension and congestive heart failure. Captopril has been developed as an analogue of bradykinin in the venom of the Brazilian pit viper Bothrops jararaca (Viperidae) following the observation that the latter agent lowered blood pressure by vasodilation. In the mean time, dozens of clinically useful and potentially therapaeutically applicable compounds from animal origin have been identified. The skin gland secretions of amphibians have been refined during millions of years of evolution to highly efficient defensive chemicals. These compounds have remarkable pharmacological activities and may also represent a treasure chest of potentially novel drugs against pathophysiological conditions. This paper addresses the importance of bioactive compounds in the skin secretions of frogs, toads, salamanders, newts, and caecilians, and elaborates on the therapeutic potential of some of them as anti-alzheimer, cardiotonic, antidiabetic, anti-HIV, analgesic, antimicrobial, and antiparasitic compounds.
\end{abstract}

\section{Introduction}

Natural products represent historically important sources of bioactive compounds with medical applicability [1]. Particularly the plant biodiversity has been explored, and this has yielded numerous breakthrough and sometimes life-saving medications [1]. Wellknown examples are the cardiotonic digoxin from foxgloves in the genus Digitalis (Plantaginaceae) [2]; the oral hypoglycemic biguanide metformin that originates from the French lilac Galega officinalis (Fabaceae) [3]; the phytosteroid sapogenin diosgenin from yam species in the genus Dioscorea (Dioscoreaceae) that serves as precursor for, among others, oral contraceptives and cortisone [4]; the antineoplastic tubulin-interfering agent vincristine from the Madagascar periwinkle Catharanthus roseus (Apocynaceae) [5]; and the cholinesterase inhibitor galantamine from snowdrops in the genus Galanthus (Amaryllidaceae) that is indicated for the treatment of mild to moderate dementia and Alzheimer's disease [6].

Other sources of successful drugs have been certain microorganisms which have produced antibiotics with a high therapeutic index. For instance, fungi in the genus Penicillium (Trichocomaceae) [7], and strains of the bacteria Streptomyces griseus (Streptomycetaceae) [8] and Micromonospora purpurea (Micromonosporaceae) [9], produced powerful antibacterial agents such as the $\beta$-lactam antibiotics ampicillin and cloxacillin, and the aminoglycosides streptomycin and gentamicin, respectively. And the highly efficacious antifungal compounds amphotericin B (for treating systemic fungal infections) and griseofulvin (for treating dermatophytic fungi) have been produced on the basis of the products from the bacterium Streptomyces nodosus (Streptomycetaceae) [10] and the fungus Penicillium griseofulvum (Trichocomaceae) [11], respectively.

The animal biodiversity, from the smallest invertebrates to the largest vertebrates, has also represented a highly useful source of novel therapeutics. For instance, the antileukemic antimetabolite cytarabine was first encountered in the Caribbean demosponge Tectitethya crypta (Tethyidae) [12]; trabectedin, an orphan drug for treating soft-tissue sarcomas and ovarian cancer, has first been identified in the mangrove tunicate Ecteinascidia turbinata (Perophoridae) [13]; and the powerful analgesic ziconitide was molded on the basis of the extremely potent conotoxins produced by predatory cone snails in the genus Conus (Conidae) [14]. Furthermore, the venom from the South American lancehead viper Bothrops jararaca (Viperidae) led to the development of angiotensin-converting enzyme-inhibiting agents such as captopril, enalapril, and lisinopril which proved ground-breaking in the treatment of hypertension [15]. And a number of compounds from insects and other arthropodes displayed encouraging pharmacological activities for developing novel therapeutics (reviewed in references [16,17].

From an evolutionary perspective, amphibians were the first to abandon aquatic life and come ashore in the Late Devonian, roughly some 370 million years ago [18]. They successfuly adapted to the challenges of land life and refined their skills for surviving. Thus, they developed strong appendages, well-attached large and sturdy pectoral and pelvic girdles, and a vertebral column that resists bending; changes in eyes, ears, and nose to properly function in air; modifications in the skin to prevent dessication and maintain water balance; adaptations to breath on lands; and effective defensive mechanisms to improve their chances for survival. The latter structures involve an astonishingly

*Correspondence to: Dennis RA Mans, Department of Pharmacology, Faculty of Medical Sciences, Anton de Kom University of Suriname. Kernkampweg 5-7, Paramaribo, Suriname, E-mail: dennismans16@gmail.com

Key words: frogs, toads, salamanders, newts, caecilians, skin secretions, bioactive compounds, novel therapeutics

Received: July 21, 2020; Accepted: August 11, 2020; Published: August 13, 2020 
diverse chemical armamentarium of skin toxins with a wide range of pharmacological activities. In this paper, some of these compounds have extensively been addressed from the point of view of their potential usefulness as candidates for new drug design programs.

\section{Background}

\section{Characteristics of amphibia}

The first amphibians had developed from primitive four-limbed animals called Tetrapodomorpha who lived in the Late Devonian, 365 to 360 million years ago [18]. The latter, in their turn, had developed from ancient bony fishes called Sarcopterygii which presumably had fleshy, lobed, paired fins with finger-like protrusions and articulations [18]. These proto-limbs allowed them to move on the sea floor and crawl on land to search for food, and evolved into legs [18]. Some of the primitive amphibians also developed primitive lungs which enabled them to breathe when the shallow Devonian swamps dried up [18]. These suppositions are supported by the body plan of Ichthyostega, an early genus of tetrapodomorph ancestors of the amphibians that lived some 370 million years ago [19]. Ichthyostega had many similarities to prehistoric sarcopterygian fishes, but also important adaptations to terrestrial life including nostrils, more efficient lungs, four strong legs, and a bony skeleton to support their weight [19].

Eventually, the tetrapods abandoned aquatic life and became the ancestors of, among others, the amphibians [18]. The amphibians became the dominant group of land animals in the Early Carboniferous, 360 to 345 million years ago [18], but still needed to return to water to lay their vulnerable shell-less eggs [18]. The Carboniferous rainforest collapse - a minor mass extinction event that occurred about 305 million years ago [20] - followed by the Permian-Triassic extinction event roughly 100 million years later [21], led to the decimation of the amphibians and the dominance of the reptiles [18,20,21]. Ultimately, only a fraction of the previously abundant amphibians survived [18].

The modern Amphibia comprise a class of ectothermic, tetrapod vertebrates which in general still characteristically start their life cycle as aquatic free-swimming larvae with gills, and metamorphose to partly terrestrial and partly aquatic adults with lungs and limbs but without a tail. The name of this animal class is derived from the ancient Greek words 'amphi and 'bios' meaning 'both' and 'life', referring to their aquatic and terrestrial forms of life. Amphibians have colonized a wide diversity of ecosystems including moist terrestrial, fossorial, and arboreal habitats as well as freshwater aquatic environments. They are in general not found in marine habitats with the exception of, among others, the crab-eating frog Fejervarya cancrivora (Dicroglossidae) that inhabits mangrove swamps and marshes in south-eastern Asia [22], and Anderson's salamander Ambystoma andersoni (Ambystomatidae) that lives in the brackish water of Lake Zacapu in the Central Mexican Plateau [23].

Most adult amphibians not only breathe through their lungs but also through their skin. As the skin is permeable to water, the animals are able to respire in water without rising to the surface, and to hibernate at the bottom of ponds. Some terrestrial frogs and salamanders even lack lungs and exclusively breathe through their skin. To make cutaneous respiration possible, the skin must always remain moist to allow the oxygen to diffuse at a sufficiently high rate. Examples of amphibians that primarily or solely rely on cutaneous respiration are aquatic species such as the Titicaca water frog Telmatobius culeus (Telmatobiidae) and the hellbender Cryptobranchus alleganiensis (Cryptobranchidae), as well as small terrestrial lungless salamanders in the family Plethodontidae.
Because of their permeable skin, amphibians are sensitive indicators of the status of the ecosystem they live in [24]. Amphibians also have mucus glands in their skin, the secretions of which help keep the skin moist and make the animals difficult to grip and hold firmly [25]. Most species have, in addition, clusters of granular skin glands or parotoid glands which secrete distasteful or poisonous substances to deter predators [25]. In many cases, the poisonousness is accompanied by bright aposemetic colors to warn or detract predators [26].

The circulatory system of juvenile amphibians (aquatic tadpoles) resembles that of fish, comprising a two-chambered heart that pumps the blood through the gills where it is oxygenated, after which it supplies the rest of the body and reenters the heart in a single loop. In most adult amphibians, the gills have disappeared and a double circulatory system has developed that includes a three-chambered heart consisting of two atria and one ventricle. Deoxygenated blood from the body enters the right atrium and passes to the ventricle that pumps it to the pulmocutaneous circuit where gas exchange occurs in the lungs and through the skin. The oxygenated blood reenters the heart via the left atrium, again passes to the ventricle, which then distributes it through the rest of the body.

The blood is filtered by two kidneys and the urine is stored in a urinary bladder. Larvae and most aquatic adult amphibians excrete nitrogenic waste as ammonia in large quantities of dilute urine. Terrestrial species have a greater need to conserve water and excrete their metabolic waste in the form of urea. Species with limited access to water such as some tree frogs excrete most of their waste as uric acid. The nervous system of amphibians is comparable to that of other vertebrates, consisting of a central brain, a spinal cord, and nerves throughout the body. However, it is more similar to that of fish than to that of reptiles, birds, and mammals: the brain consists of three components, the forebrain, the midbrain, and the hindbrain, which are mainly involved in olfaction, vision, and motor skills, respectively.

As most amphibians locate prey by sight, binocular vision is their most important sense. Frogs and toads are also able to hear both low frequency sounds (usually from predators) and high-frequency sounds (mostly from mates), while salamanders can only detect low vibrations via the ground. Many amphibians have chemoreceptors in the mouth, on the tongue, and in the skin which help them recognize potential mates, locate food, and detect noxious and poisonous chemicals. Frogs and toads have a larynx and vocal chords which enable them to make species-specific sounds to mark their territory, give distress calls, and attract females.

Most amphibian larvae are herbivores and live on algae and different plant matter, while most adults are carnivores. In general, they swallow their prey whole, which is then passed via a short esophagus into the stomach where the enzyme chitinase helps digest the chitinous cuticle of arthropod prey. Other digestive enzymes are produced by the pancreas, the gall bladder, and the relatively large liver.

Depending on the order, fertilization occurs externally or internally. In all cases, the eggs lack coverings and must be laid in a moist environment to develop into tadpoles. Parental care is only seen in about $10 \%$ of amphibians, and in these cases it usually is the male that protects the nest and broods the eggs. The tadpoles of most species undergo a dramatic metamorphosis which may involve, among others, losing their tail, fins, and gills and developing lungs and limbs [27] Metamorphosis is incomplete in some cases which retain, for instance, their gills and/or tails as adults [27]. Metamorphosis in all anurans is regulated by a balance between blood concentrations of thyroxine 
which stimulates metamorphosis, and those of prolactin which counteracts thyroxine's effect [27]. After metamorphosis, the redundant organs are removed by apoptosis [27]. There is considerable variation in developmental responses to specific environmental circumstances, and this results in many modifications of the process of metamorphosis, even within the same species [28].

\section{Classification of amphibia}

The Amphibia are classified into three subclasses, namely the extant Lissamphibia which include all modern amphibians, as well as the extinct Lepospondyli and Temnospondyli which lived during the Paleozoic and Early Mesozoic Eras, roughly 541 to 252 million years ago (Figure 1) [29]. The lissamphibians are subdivided into the orders Anura or Salientia, Urodela or Caudata, and Gymnophiona or Apoda (Figure 1). The Anura or Salientia consist of frogs, toads, and their relatives, and represent about $88 \%$ of the total number of about 8,212 currently known amphibian species [29]. Most anurans inhabit moist habitats but there are some species that live in deserts. Fertilization occurs externally, and the eggs and larvae are typically aquatic while the adults are in general terrestrial. The tadpoles have tails which disappear after metamorphosis. The tail-less adults develop muscular hind limbs and webbed feet.

The Urodela or Caudata comprise the salamanders, newts, and their relatives, and encompass $9 \%$ of the amphibian species described today [29] which are mostly encountered in the northern hemisphere. Both names of this amphibian order can freely be translated as 'to bear a tail', since most of its members keep their tail after metamorphosis. Some species also retain the external gills characteristic for their larval stages during adulthood. Urodela reproduce by internal fertilization without actual copulation: the male deposits a packet of sperm that is picked up and stored by the female, and the eggs are fertilized as they leave its body through the cloaca.

The Gymnophiona or Apoda encompass the caecilians and their relatives, and make out the remaining $3 \%$ of the currently described amphibian species (Figure 1) [29]. These amphibians are 'naked and limbless like a snake', almost blind (their vernacular name 'caecilians' is derived from the Latin word 'caecus', meaning 'sightless' or 'blind'), and are in general found in tropical regions where they mostly live in underground burrows. Unlike anurans and urodeles, members of the Gymnophiona reproduce by internal fertilization following internal insemination. Some species have live births and some lay eggs.

The smallest amphibian in the world (as well as the smallest vertebrate in the world) is the narrow-mouthed frog Paedophryne amanuensis (Microhylidae) [30]. This animal attains an average body size of only $7.7 \mathrm{~mm}$ and was discovered near Amau village in southern Papua New Guinean [30]. The largest extant amphibian

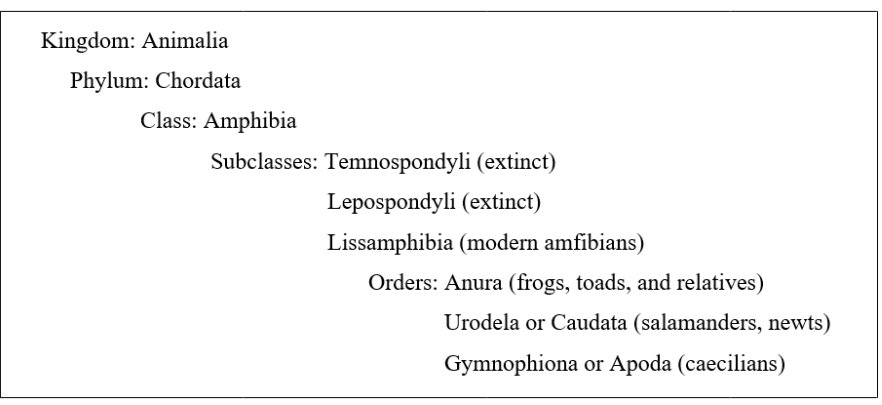

Figure 1. Taxonomy of the amphibia in the animal kingdom is the fully aquatic Chinese giant salamander Andrias davidianus (Cryptobranchidae) that can reach a weight of $50 \mathrm{~kg}$ and a length of $180 \mathrm{~cm}$, and can be encountered in the Yangtze river basin of central China [31]. However, with an average length of $9 \mathrm{~m}$ and a weight of over $2,000 \mathrm{~kg}$, the extinct Prionosuchus was the largest amphibian that ever existed [32]. Prionosuchus was a genus of crocodile-like tetrapode primitive amphibians that lived during the early Perm, some 299 to 272 million years ago [32]. Fossilized fragments of this animal have been discovered in the Pedra do Fogo Formation in the Parnaíba Basin of north-eastern Brazil [32].

\section{Defenses of amphibia}

Many amphibians are relatively small and slow-moving creatures with tender bodies and thin skins, and do not have claws, canine teeth, defensive armor, and/or spines. Furthermore, they usually occur in high population densities, are good sources of protein, and contain little indigestible material. Thus, amphibians generally represent easy and attractive prey for predators. For this reason, they have developed a broad arsenal of defensive mechanisms to prevent or minimize predation and increase their chances of survival in all stages of their life cycle. Some of these mechanisms are comprehensively dealt with in the sections about the different lissamphibian orders hereunder.

Among the most distinctive defense mechanisms of all amphibians are the above-mentioned mucous and granular glands in their skin $[25,33,34]$, the secretions of which keep the animals moist and slippery and difficult to grip and often represent powerful defensive chemicals $[25,33,34]$. The mucous glands are widely distributed throughout the integument and continuously secrete their contents onto the skin surface $[25,33,34]$. The mucous secretion acts as a physical barrier against pathogens, restricts loss of water, provides lubrication to the skin, reduces friction under water, and minimizes mechanical damage on land $[25,33,34]$. In some species - such as the African clawed frog Xenopus laevis (Pipidae) - it is also distasteful and toxic, providing the animals an opportunity to escape when ingested by predatory snakes [35].

The granular or parotoid glands are in general found in clusters on the skin, mainly behind the ears in toads, along the back in frogs, behind the eyes in salamanders, and on the upper surface in caecilians [25]. These glands synthesize and secrete a large variety of bioactive substances which serve a variety of protective and defensive purposes $[25,36,37]$. Some have powerful antimicrobial properties which protect the animals against a variety of microbial pathogens, others give them an unpleasant taste or smell, and still others act as irritants, hallucinogens, convulsants, nerve poisons, or vasoconstrictors $[38,39]$. At this moment, hundreds of bioactive peptides, bioactive amines, alkaloids, and steroids have been identified in amphibian granular skin secretions $[25,36,37]$. In most cases, the toxic ingredients in the secretions are derived from the poisonous plants and small insects the animals consume or live amongst $[25,40]$, but the Australian corroboree frogs Pseudophryne corroboree and Pseudophryne pengilleyi [41] and certain members of the Salamandridae family (true salamanders and newts) [42] synthesize the toxic compounds themselves.

As also indicated earlier, many toxic amphibians combine their toxicity with aposematic coloring to warn potential predators to keep distance [43]. Well-known examples are the poison dart frogs in the genus Phyllobates (Dendrobatidae) from Central and South America [44], and the fire salamander Salamandra salamandra (Salamandridae) from southern and central Europe [45]. These amphibians combine the production of the highly toxic alkaloids curare 
and samandarin, respectively, in their skin secretions with vividly bright skin coloration. Some species such as rocket frogs in the genus Colostethus (Dendrobatidae) and Zaparo's poison frog Allobates zaparo (Aromobatidae) have cashed in on the success of their aposematic relatives by applying Batesian mimicry, i.e., using equally extremely bright (pseudoaposematic) coloration while having only minimal or no toxicity $[44,46]$.

Some of the defensive chemicals of amphibia elicit remarkable pharmacological effects and may be exploited as lead compounds for developing novel diagnostic compounds and therapeutic drugs [47]. A few of these compounds from Anura, Urodela, and Gymnophiona are comprehensively addressed hereunder.

\section{Anura}

\section{Generalities about anura}

The Anura or Salientia include 7,243 species of living frogs and toads and as mentioned above, represent the largest order of the Amphibia, comprising nearly $90 \%$ of this class of animals [29]. Frogs and toads are sometimes distinguished from each other with respect to the structure of their skin and their habitat: frogs would have in general smooth and moist, slimy skin and would spend most of their life in or near water, while toads would have dry and warty skin and would spend their life much more on land. However, taxonomically, this distinction is incorrect. All anurans - including so-called toads - are frogs, and only members of the family Bufonidae are considered 'true toads'. Thus, the Panamanian golden frog Atelopus zeteki has a smooth skin and is a true toad' in the toad family Bufonidae, whereas the European fire-bellied toad Bombina bombina has a slightly warty skin but is a 'frog' in the family Bombinatoridae.

A unifying characteristic of all anurans is the absence of a tail, which is captured in the name 'Anura' of the order that is derived from the ancient Greek words ' $a(n)$ ' and 'ourá' meaning 'without' and 'tail', respectively. In addition, all anurans have a relatively short trunk; broad, flat heads; and relatively long hind limbs which fold underneath them, enabling them to assume a squatting position and to leap and jump (the synonym 'Salientia' for this order is derived from the Latin verb 'salere' meaning 'to jump'). With the exception of polar areas, frogs and toads have colonized all ecological niches throughout the world, particularly damp habitats and trees in tropical areas. As mentioned earlier, the smallest anuran in the world is the narrow-mouthed frog P. amanuensis from Papua New Guinea that measures about 7.7-millimeter [30]. The largest is the goliath bullfrog Conraua goliath (Conrauidae) from western Africa that can grow up to 32 centimeters in length and weigh up to 3.25 kilograms [48].

The oldest members of the frog lineage probably were extinct proto-frog-like amphibians of the genus Triadobatrachus that had lived during the Early Triassic about 250 million years ago [49]. Millions of years later, in the Early Jurassic (about 190 million years ago), modern frogs arose, the earliest example of which was Prosalirus (Prosaliridae) [50]. These early anurans gave rise to the current 7,243 species which can be grouped in 459 genera, 54 families, and 3 suborders, the Archaeobatrachia, Mesobatrachia, and Neobatrachia [29].

The suborder Archaeobatrachia includes 28 relatively small species of primitive anurans which are placed in 4 families and 6 genera [29]. Well-known examples are the fire-bellied toads belonging to the genus Bombina in the family Bombinatoridae [29]. They are considered 'primitive' because they have characteristics that were common in extinct frogs and toads but are no longer present in the more modern suborders, most notably free vertebrae that are not attached to the ribs instead of fused vertebrae [29]. The Archaeobatrachia are mainly found in Eurasia, New Zealand, the Philippines, and Borneo [29]. The suborder Mesobatrachia consists of 244 species in 16 genera and 6 families of evolutionary more advanced frogs and constitutes the second-largest of the Anura suborders. There are five fossorial families and one obligatorily aquatic family, the Pipidae (tongueless frogs) from Africa and South America such as the Surinam toad Pipa pipa [29]. The suborder Neobatrachia has evolved later than the Mesobatrachia and comprises the remaining frogs including the most commonly known species throughout the world such as those in the families Hylidae (true tree frogs), Microhylidae (narrow-mouthed frogs), Bufonidae (true toads), and Ranidae (true frogs) [29]. With roughly 5.000 species in over 350 genera and more than 30 families, it is by far the largest anuran subgroup, comprising over $96 \%$ of all existing frogs and toads [29].

Fertilization in Anura mainly occurs externally, taking place by amplexus, involving the male grasping the female with its front legs and covering the eggs with sperm as they are released from the female's body [51]. After fertilization, the life cycle of most anurans starts in water when the eggs hatch into limbless larvae with gills. Within a few days they develop into tadpoles with limbs, lungs, and a relatively long, spiral-shaped gut to digest the vegetarian diet they live off. Eventually, the tadpoles undergo metamorphosis to terrestrial air-breathing animals, involving, among others, the development of the lungs and the disappearance of the gills, apoptosis of the tail, modifications for hearing and (stereoscopic) vision as well as for locomotion on land, changes in the skin to prevent dehydration and facilitate skin breathing, as well as adaptions for a carnivorous lifestyle [52]. Remarkably, all these changes can occur within twenty-four hours [52].

Anurans have developed various strategies to defend themselves against attack or predation in all stages of their life cycle. For instance, the eggs from the red-eyed tree frog Agalychnis callidryas (Phyllomedusidae) escape predation by immediately hatch in response to vibrations caused by a potential predator and drop from the undersides of the leaves they have been laid on into the ponds beneath [53]. The (non-toxic) leaf litter frog Ischnocnema henselii (Brachycephalidae) feigns death as a way to avoid predation [54], a behavior called thanatosis after Thanatos, the god of death in ancient Greece. When threatened, the red tree frog Leptopelis rufus (Arthroleptidae) combines thanatosis with the release of a strong ammonia-like smell through its open mouth, adding to the illusion of a dead frog [54].

Furthermore, the Pacific tree frog Pseudacris regilla (Hylidae) uses camouflage, changing its skin color depending on the time of year and the general background color [55]. The European common toad Bufo bufo (Bufonidae) adopts a characteristic aggressive stance with its body inflated, its hindquarters raised, and its head lowered when confronted with an assailant [54]. When grasped, the smoky jungle frog Leptodactylus pentadactylus (Leptodactylidae) emits a high-pitched scream to startle the assailant [54]. And when facing danger, the American bullfrog Lithobates catesbeianus (Ranidae) crouches down with eyes closed and head tipped forward, placing the parotoid glands in the most effective position for defense while the glands on its back begin to ooze noxious secretions [54].

Biochemical and pharmacological studies have shown the existence of hundreds of defensive chemicals in the skin secretions of anurans, including alkaloids, peptides, proteins, steroids, and biogenic amines [56]. These compounds mainly come from the ants and other arthropods they consume [57-61], and may have irritating, hallucinogenic, convulsant, nerve-poisoning, or vasoconstrictive properties [56]. These 
meaningful pharmacological properties suggest that ingredients of anuran skin secretions could be useful against human diseases.

\section{Bioactive compounds from anura}

Anurans have been the subject of numerous folktales, fables, myths, and legends, ranging from their 'usefulness against ugliness and wickedness' according to the Chinese 'Book of Songs' from 3,000 years ago [62] to the many variations of the Brothers Grimm fairy tale 'The Frog Prince' in which the protagonist is transformed into a handsome prince after having been kissed by the beautiful princess [63]. Likewise, the pharmacological properties of anurans - either perceived or genuine - have been known for a long time. Secretions from the parotoid glands from frogs and toads, but also preparations from whole animals or from their bones or muscle tissues, have been used for millennia for treating, among others, infections, bites, heart disorders, hemorrhages, allergies, inflammation, pain, and even cancer and AIDS [64].

For instance, in China and Japan, the dried secretions from the skin glands of the Asiatic toad Bufo gargarizans (Bufonidae) or the Asian common toad Duttaphrynus melanostictus (Bufonidae) called venenum bufonis, toad cake, or Chansu (Senso) in China and Kyutshin in Japan, are since long used to treat cancer $[65,66]$. These substances have also extensively been used for hundreds of years, either singly or in combination with other compounds, as analgesics, local anesthetics, diuretics, and antimicrobial substances $[65,66]$. Notably, an injectable form of Chansu called Huachansu has officially been approved for use in traditional Chinese medicine as an antineoplastic agent, particularly for treating liver and pancreatic cancer $[67,68]$.

Ongoing research efforts are showing that many of these tradional applications may have a scientific rationale and, more importantly, may help in the identification of lead compounds for producing novel therapeutics. For instance, various members of the harlequin toads in the genus Atelopus (Bufonidae) produce bufadienolide and tetrodototoxin [69], as well as zetekitoxins [70] and tetrodototoxin analogues called chiriquitoxins [71] in their parotoid glands. Bufadienolides and zetekitoxins are powerful cardiotoxins that are able to reduce cardiac rhythm [70], while tetrodotoxin and chiriquitoxins are neurotoxins which can cause muscle paralysis and respiratory arrest [71]. For these reasons, these compounds may serve as leads for developing novel heart medications and analgesics.

Furthermore, preparations from anuran venoms including toad cake showed encouraging in vitro antitumor activity that might be associated with the inhibition of cell proliferation, the promotion of angiogenesis of tumor endothelial cells, the induction of apoptosis, the promotion of differentiation, and the stimulation of tumor-directed immune responses [72-74]. Comparable results were obtained with various isolated bufadienolides [72-74]. Thus, ingredients of anuran skin secretions may also turn out useful against cancer.

Numerous studies have demonstrated the antimicrobial properties of peptides from anuran skin secretions. A few examples are bombinins in European species of fire-bellied toads in the genus Bombina [75]; magainins in the African clawed frog X. laevis [76]; dermaseptin in the waxy monkey tree frog Phyllomedusa sauvagii (Phyllomedusidae) [77]; bombinin-like peptides in two species of Bombina [78,79]; brevinins in the Nagoya Daruma pond frog Rana brevipoda porsa (Ranidae) [80]; and rugosins in the Japanese wrinkled frog Rana rugosa (Ranidae) [81]. It is conceivable that some of these compounds will replace currently available antibiotics which are becoming less efficacious due to the development of microbial resistance.
Together, these data indicate the potential of anuran glandular skin poisons for developing novel heart medications, analgesics, anticancer agents, antibiotics, and a host of other therapeutics [82]. Hereunder, ingredients from anuran glandular skin secretions with potential applicability as anti-alzheimer, cardiotonic, antidiabetic, and anti-HIV compounds is in detail addressed.

\section{Anti-alzheimer's compounds}

Alzheimer's disease is a progressive neurodegenerative disorder characterized by a gradual decline in cognitive, behavioral, and social skills that disrupts the ability to function independently, and culminates in the loss of bodily functions and, ultimately, death [83]. This condition is the most common cause of dementia in many parts of the world, affecting about 50 million individuals in 2019 and accounting for more than two-thirds of cases of senile dementia [84]. Its incidence in 2019 was about 10 million and doubles every five years after the age of 65 years due to continued aging of the world population [84], and the prevalence is anticipated to reach over 115 million by 2050 [85].

The etiology of Alzheimer's disease is complex and still incompletely understood, but is believed to involve an interplay of genetic, lifestyle, and environmental factors that increasingly affects the brain with older age [83-85]. These factors contribute to various degrees to the hallmarks of the disease, namely abnormalities in the cerebral cholinergic system, and the deposition of amyloid plaques and neurofibrillary tangles in certain areas in the brain [86-88]. The cholinergic system plays an important role in the regulation of learning and memory processes, and progressive loss and malfunctioning of choline-containing neurons in the brain are believed to substantially contribute to the cognitive decline in patients with Alzheimer's disease [86]. Amyloid plaques are dense, insoluble buildups of $\beta$-amyloid peptide and cellular material outside and around neurons that interfere with neuron-to-neuron communication at synapses $[87,88]$. Neurofibrillary tangles are aggregates of the microtubule-associated protein tau which have become hyperphosphorylated and accumulate inside neurons, blocking the transport of nutrients and other essential molecules inside neurons [87,88]. Other changes in Alzheimer's disease include chronic inflammation, atrophy of the brain, and loss of normal brain function as a result of the immune response of microglia on the presence of $\beta$-amyloid and tau proteins as well as other debris, cell loss, and the increasing inability of the brain to metabolize glucose [8789]. It is gradually becoming clear how all these abnormalities work together in causing Alzheimer's disease [89].

So far, there are no treatments to halt or reverse the progression of Azheimer's disease, although some medications may temporarily provide symptomatic improvement [90]. Since a deficit in the cerebral cholinergic system is a consistent and early finding in Alzheimer's disease, many drug discovery and development efforts have focused on inhibiting acetylcholinesterase and/or butyrylcholinesterase activities, thus preventing acetylcholine turnover, restoring synaptic levels of this neurotransmitter, enhancing cholinergic transmission, and decreasing the formation of amyloid plaques and tau tangles [91]. As a result, cholinesterase inhibitors such as galantamine, rivastigmine, and donepezil are currently the main medications for the treatment of Alzheimer's disease [90,91]. However, these medications only temporarily relieve symptoms while having substantial side effects, and often lose their effect as the disease progresses $[90,91]$.

For these reasons, the search for novel anti-alzheimer medications with an improved therapeutic index is ongoing. Among these compounds are ingredients of the skin extracts from certain anuran species. For 
instance, the skin extracts from several South American hylidan species, namely Cordoba's tree-frog Hypsiboas cordobae (Figure 2), the lesser swimming frog Pseudis minuta, the Montevideo tree frog Boana pulchella, the swimming frog Pseudis platensis, and the dwarf treefrog Dendropsophus nanus displayed encouraging acetylcholinesterase- and butyrylcholinesterase-inhibiting activities in vitro [92,93]. Essentially similar results were found with the skin extracts from the butter frog Leptodactylus latrans, Cei's white-lipped frog Leptodactylus chaquensis, the mustached frog Leptodactylus mystacinus, Hensel's swamp frog Pseudopaludicola falcipes, and the Helvetia dwarf frog Physalaemus santafecinus in the Leptodactylidae family; and that from the twocolored oval frog Elachistocleis bicolor belonging to the Microhylidae [92]. All the skin extracts also exhibited in vitro monoamine oxidase B inhibitory activity and displayed in vitro antioxidant activity [92], suggesting that they may target additional pathways that may be of relevance to the pathophysiology of Alzheimer's disease [85,89].

The identity of the chemicals in the skin extracts that were responsible for these observations is not clear. However, in the case of that of $B$. pulchella, the in vitro (butyryl)cholinesterase-inhibiting activity might be attributed to low molecular weight-compounds [94] as well as the protein Hp-1935 isolated from this extract $[95,96]$. Hp is an abbreviation of Hypsiboas pulchellus, a synonym for B. pulchella, and Hp-1935 had shown notable antimicrobial activity in earlier studies with Mycobacterium tuberculosis [95] as well as Escherichia coli and Staphylococcus aureus [97]. The results from molecular dynamics simulations suggested that Hp-1935 is among the most potent natural peptides against acetylcholinesterase [96]. In the mean time, a number of analogues of Hp-1971 have been synthesized that displayed potent inhibition of acetylcholinesterase and butyrylcholinesterase activity [98]. These developments hold the promise to eventually apply anuranderived products in the clinic against Alzheimer's disease.

\section{Cardiotonic compounds}

Heart failure is a complex clinical syndrome characterized by the reduced ability of the heart to pump and/or fill with blood [99]. In other words, in these patients, the cardiac output is not sufficient to meet the metabolic demands of the body [99]. Heart failure has been characterized as an emerging worldwide threat, affecting 64.34 million individuals in 2017 and accounting in that year for USD 346.17 billion expenditure and 9.91 million years lost due to disability [100]. This condition poses the largest disease burden in individuals older than 60 years, and prevalence as well as years lost due to disability have increased by $3.9 \%$ and $4.5 \%$, respectively, in very elderly people during the last 28 years [100].

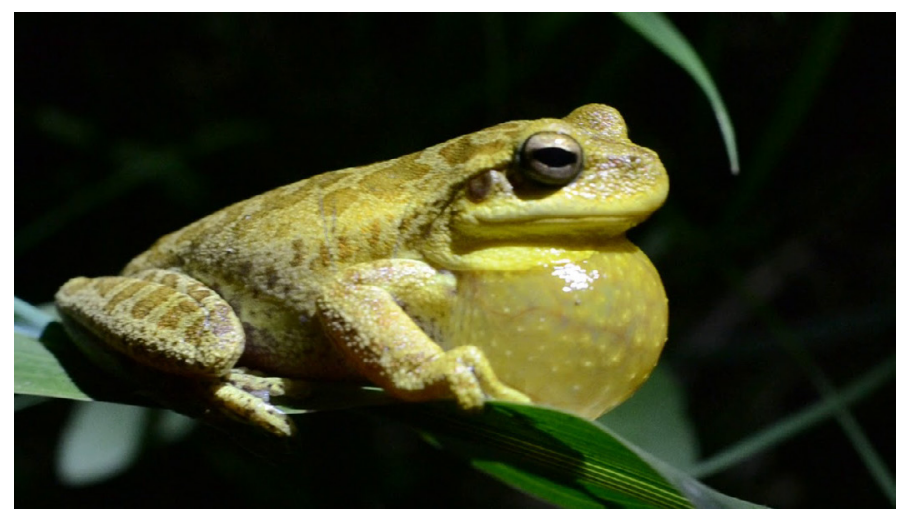

Figure 2. The Cordoba tree frog Hypsiboas cordobae (Hylidae) (https://images.app.goo. $\mathrm{gl} /$ Xo8eS6haXdsZ9im26)
The cardiac glycoside digoxin from foxglove plant species belonging to the plant genus Digitalis (Plantaginaceae) has been used for centuries for treating heart failure owing to its cardiotonic effects [101]. Digoxin inhibits the $\mathrm{Na}^{+} / \mathrm{K}^{+}$-ATPase transport system in the plasma membrane of cardiomyocytes, which leads to higher intracellular $\mathrm{Na}^{+}$concentrations, a reduced efficacy of the $\mathrm{Na}^{+} / \mathrm{Ca}^{2+}$ exchanger, and higher intracellular $\mathrm{Ca}^{2+}$ concentrations, leading to increased contractility, reduced velocity of electric conduction, and a decreased heart rate [101]. The end results is improved cardiac output and ejection fraction as well as reduced filling pressures and pulmonary capillary wedge pressure while heart rate is hardly affected [101]. In addition, digoxin reduces the velocity of electric conduction of the vagal nerve which, via a reflexive reduction of sympathetic transmission, also contributes to reduction of the heart rate [101].

Despite the availability of newer and more efficacious treatments for heart failure such as angiotensin-converting enzyme inhibitors, angiotensin II receptor blockers, angiotensin-receptor neprilysin inhibitors, If channel blocker, $\beta$-blockers, aldosterone antagonists, diuretics, anticoagulants, and cholesterol-lowering drugs (statins) [102], digoxin is still widely used in this condition, particularly in treatment-resistant patients [101]. However, the major drawbacks of digoxin is its narrow therapeutic index [101]. For these reasons, the search for novel clinically useful cardiac glycosides is ongoing.

Among these are the above-mentioned anuran skin gland preparations called venenum bufonis, toad cake, Chansu (Senso), and Kyushin $[65,66]$. These substances elicited notable cardiotonic effects in an in vivo rabbit model of heart failure as well as in anesthetized open-chest guinea pigs or dogs, accomplishing an increase in mean aortic pressure, left ventricular pressure and maximal rate of rise of left ventricular pressure, and a decrease in left ventricular end-diastolic pressure and systemic vascular resistance without significantly changing mean blood pressure and heart rate [103-107]. These effects were comparable to those caused by digoxin [103], and the benefical effects on the heart might be aided by stimulation of $\beta$-adrenoceptors [108] and diuresis [109]. Importantly, Senso and Kyushin caused cardiac arrhythmia - a common side effect of digoxin [101] - at much higher doses than digoxin, suggesting that they had a broader safety margin than digoxin [106]. Interestingly, Kyushin inhibited experimentally induced arrhythmia in guinea pigs, presumably through an inhibitory effect on the conduction system as well as by potentiating the decrease in heart rate by the parasympathetic nervous system [110].

The main ingredients of Chansu and Kyushin are cardiac glycosides including bufadienolide glycosides such as bufalin, resibufogenin, and cinobufagin $[110,111]$. These compounds elicited cardiotonic effects comparably to digitoxin and ouabain in a guinea-pig working heart preparation and in experimentally induced heart failure in a perfused guinea-pig heart [111]. Furthermore, commercially available bufolin inhibited $\mathrm{Na}^{+} / \mathrm{K}^{+}$-ATPase activity in normotensive rats comparably to ouabain and ouabagenin [112], and both bufolin and cinobufagin inhibited myocardial $\mathrm{Na}^{+} / \mathrm{K}^{+}$-ATPase activity in the plasma membrane of cardiomyocytes and increased the myocardial contractile force in open-chest guinea pigs without affecting the heart rate [113].

In addition to bufadienolides, bufadienolide-like compounds marinoic acid and marinosin have been identified as inhibitors of $\mathrm{Na}^{+} /$ $\mathrm{K}^{+}$-ATPase activity and thus potential carditotoninc compounds in the skin of the cane toad Rhinella marina (Bufonidae) (Figure 3) [114,115]. These compounds might be related to the bufadienolides because of some structural similarities and their inhibitory effect on $\mathrm{Na}^{+} / \mathrm{K}^{+}-$ ATPase activity, and competed with ${ }^{3} \mathrm{H}$-ouabain for binding to the 


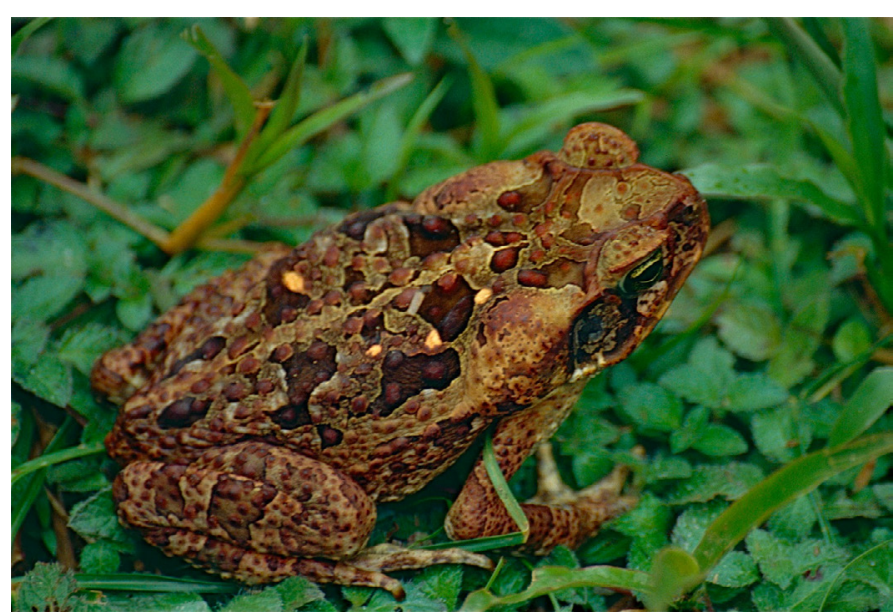

Figure 3. The cane toad Rhinella marina (Bufonidae) (https://images.app.goo.gl/ korNjV649ZnLMhrb9)

digitalis receptor site on $\mathrm{Na}^{+} / \mathrm{K}^{+}$-ATPase $[114,115]$. These observations, together with those from the previous alineas, warrant further research on bufadienolides and bufadienolide-related compounds in anuran skin gland preparations as improved glycoside cardiotonics.

\section{Antidiabetic compounds}

Diabetes mellitus is a metabolic disorder characterized by chronic hyperglycemia (fasting plasma glucose $>7.0 \mathrm{mmol} / \mathrm{L}$, or plasma glucose $>11.1 \mathrm{mmol} / \mathrm{L}$ two hours after a meal) as a result of insufficient insulin secretion, insufficient insulin action, or both [116]. The defective insulin secretion is the result of inappropriate functioning of the $\beta$ cells of the pancreas, while the inadequate insulin action is generally associated with resistance of the target tissues to insulin [116]. The resulting abnormalities can lead to distinctive complications of heart, blood vessels, eyes, kidneys, and nerves which can eventually be fatal [116].

Diabetes mellitus is among the most widespread non-communicable diseases in many parts of the world, with a global morbidity and mortality in 2019 of 463 million and 4.2 million individuals, respectively [117]. These numbers are rising rapidly: in 2011, the global prevalence in adults was $6.4 \%$ or 350 million, but it is anticipated to reach $7.3 \%$ or 700 million by 2045 [117]. Health expenditure for diabetes mellitus amounted in 2019 to USD 760 billion, i.e., approximately $10 \%$ of total spending on adults [117]. Still, the proportion of individuals with type 2 diabetes mellitus is increasing in most countries [117], with $79 \%$ of adult patients living in low- and middle-income countries in 2019 [117].

Treatment of diabetes mellitus involves both the adoption of lifestyle changes, particularly an adjusted diet and regular exercise, and the intake of drugs [118]. Patients with type 1 diabetes mellitus are treated with one of the nay dosage forms of insulin [118]. Those with type 2 diabetes mellitus may be prescribed oral antihyperglycemic drugs, injectable glucagon-like peptide-1 receptor agonists, insulin, or a combination of these agents [118]. In all cases, regular monitoring of blood glucose levels is essential to prevent complications [118]. The therapy to be delivered is determined by the type of diabetes mellitus involved, i.e., type 1 diabetes mellitus (caused by autoimmune $\beta$-cell destruction and ending with absolute insulin deficiency), type 2 diabetes mellitus (caused by a progressive loss of $\beta$-cell insulin secretion along with insulin resistance), gestational diabetes mellitus (occurring in the second or third trimester of pregnancy) and specific types of diabetes due to other causes [119].

Despite the large armamentarium of antidiabetic medications, each of these compounds have their specific drawbacks [118]. For instance, metformin is the first-line medication for type 2 diabetes mellitus, but is infamous for gastrointestinal upset, including diarrhea, cramps, nausea, vomiting, and increased flatulence [120]. For these reasons, the search for improved antidiabetic medications from 'unusual' sources is ongoing. These efforts have led to the development and approval of glucagon-like peptide-1 receptor agonist such as extenatide, synthetic versions of exendin-4, a hormone found in the saliva of the Gila monster Heloderma suspectum (Helodermatidae) [121]. These medications are also called incretin mimetics because they simulate the actions of endogenous incretin hormones that the body produces to stimulate insulin release and decrease excessive glucagon release in response to a meal [121]. They are subcutaneously administered before the first and last meal of the day, and are used along with diet and exercise to control blood sugar in adults with type 2 diabetes [121].

More recently, the skin secretions of several species of frogs have also been found to synthesize potent incretin mimetic insulinotropic peptides with therapeutic potential [122-125]. Well-studied examples are pseudin-2 from the paradoxical frog or shrinking frog Pseudis paradoxa (Hylidae) (Figure 4); tigerinin-1R from the Chinese edible frog Hoplobatrachus rugulosus (Dicroglossidae); magainin-AM2 from the volcano clawed frog Xenopus amieti (Pipidae); hymenochirin-1B from the Congo dwarf clawed frog Hymenochirus boettgeri (Pipidae); caerulein precursor fragment (CPF) peptides from the African clawed frog X. laevis and the Cameroon clawed frog Xenopus epitropicalis (Pipidae); esculentin-2CHa from the Chiricahua leopard frog Lithobates chiricahuensis (Ranidae) [122-125]. These compounds stimulated the release of insulin from cultured BRIN-BD11 cells and isolated mouse islets [125-130], and reduced body weight, improved glucose tolerance following a high-fat diet, enhanced insulin release and insulin sensitivity, and decreased glucagon and plasma glucagon-like peptide 1 in high fat-fed laboratory mice with impaired glucose tolerance and insulin resistance [126,128,131-133].

Importantly, none of these compounds were cytotoxic in vitro [125-128,130] or in vivo [133]. Other encouraging properties for their use as antidiabetic agents are the resistance to degradation by plasma enzymes in vitro for up to $8 \mathrm{~h}$ (in the case of magainin-AM2 [128]), the capacity to lower circulating triglyceride levels by (in the case of CPF-

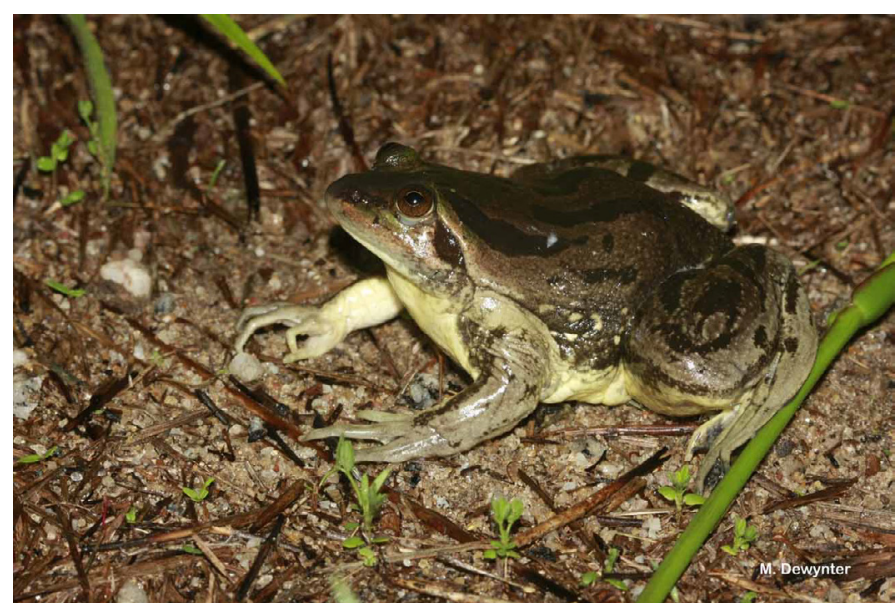

Figure 4. The paradoxical frog or shrinking frog Pseudis paradoxa (Hylidae) (https:// images.app.goo.g1/VXrm2yBbQDhtr4Tu9) 
SE1 [132]), the promotion of $\beta$-cell proliferation and survival in vivo (in the case of esculentin-2CHa [133]), and the positive results with the magainin analogue pexiganan in the treatment of infected foot ulcers in patients with diabetes [134]. Nevertheless, more work needs to be carried out before the antidiabetic therapies based on frog secretions can be tested on human patients.

\section{Anti-HIV compounds}

Human immunodeficiency virus infection and acquired immune deficiency syndrome (HIV/AIDS) represent a syndrome that is caused by infection with the human immunodeficiency virus (HIV) [135]. HIV/ AIDS is characterized by a progressively weakening immune system and a greatly increased risk of contracting (opportunistic) infections with a more serious course than in healthy individuals [135], and developing tumors which are rare in people who have normal immune function such as Kaposi's sarcoma $[135,136]$. The late symptoms of HIV infection are referred to as acquired immunodeficiency syndrome (AIDS) [135]. There were worldwide about 38 million cases of HIV infection in 2019, and in that year 690,000 patients died from their disease [137]. The total worldwide death toll of HIV/AIDS between the first identified case in the 1980s and 2019 amounted to roughly 32.7 million [137]. Not surprisingly, HIV/AIDS is considered a pandemic, although its spread has been largely controlled by preventive measures and adequate medications [138].

The causative agents of HIV/AIDS are the lentiviruses HIV-1 and HIV-2 [135], which are probably common in other primates including chimpanzees, and have first spread to humans in west-central Africa in the early-to-mid $20^{\text {th }}$ century [139]. HIV-1 is more virulent and more infective than HIV-2, and is the cause of the majority of HIV infections globally [140]. AIDS was first recognized by the United States Centers for Disease Control and Prevention in 1981, and its cause - HIV infection - was identified in the early part of the decade [141]. HIV primarily infects $\mathrm{CD} 4^{+} \mathrm{T}$ cells [142], which play key roles in the adaptive immune system, among others, by releasing cytokines which help activate cytotoxic $\mathrm{CD} 8^{+} \mathrm{T}$-cells to fight off viruses and other foreign invaders [143].

So far, there is no cure or vaccine for HIV/AIDS. Patients receive highly active antiretroviral treatment (HAART) which can slow the course of the disease and may lead to a near-normal life expectancy [144], as well as preventive and active treatment of opportunistic infections [145]. HAART consists of combinations of at least three medications belonging to at least two classes of antiretroviral agents [146]. The individual drugs that make up HAART interfere with distinct steps in the HIV infection cycle and include nucleoside reversetranscriptase inhibitors and nucleotide reverse-transcriptase inhibitors, non-nucleoside reverse-transcriptase inhibitors, protease inhibitors, entry inhibitors or fusion inhibitors, and integrase inhibitors [146]. Currently, the World Health Organization recommends the combination of the nucleoside reverse-transcriptase inhibitor lamivudine, the nucleotide reverse-transcriptase inhibitor tenofovir, and the integrase inhibitor dolutegravir as first-line treatment, with the non-nucleoside reverse-transcriptase inhibitor efavirenz instead of dolutegravir as an alternative [147]. Combinations that include protease inhibitors are used if the above regimen loses effectiveness [147].

Amphibian skin secretions have been shown to contain peptides with strong antiviral properties in in vitro systems. A few examples are brevenin-1 from the Nagoya Daruma pond frog R. brevipoda porsa (Figure 5) that displayed activity against herpes simplex viruses types 1 and 2 [148]; esculentin-2P and ranateurin-2P from the northern leopard frog Lithobates pipiens (Ranidae) that inactivated frog virus 3 and channel catfish herpes virus [149]; and dermaseptins from several hylidan frogs - particularly those in the genera Agalychnis and Phyllomedusa - that exerted potent activity against human papilloma virus and herpes simplex virus [150], herpes simplex virus 1 and 2 including an acyclovir resistant strain [151,152], and rabies virus in mice [153].

Likewise, several ingredients from anuran skin secretions were found to elicit anti-HIV activity. This held true for, for instance, dermaseptins-S4 and S9 from certain species in the genus Phyllomedusa $[154,155]$ which reduced cell-free and cell-associated HIV-1 transmission, and impaired HIV-1 attachment to P4-CCR5 indicator cells, human primary T lymphocytes, and monocyte-derived dendritic cells cells [154]. Notably, certain analogues of these peptides displayed less cytotoxicity to normal cells without affecting the anti-HIV activity $[154,155]$. Furthermore, a heme-containing protein called BAS-AH isolated from skin secretions of the Asiatic toad B. gargarizans inhibited HIV-1 infection and replication at concentrations that showed little effect on the viability of host cells, possibly by interfering with the activity of HIV-1 reverse transcriptase [156]. The bombinin-like antimicrobial peptide maximin 3 from skin secretions of the Chinese red belly toad Bombina maxima (Bombinatoridae) also elicited significant anti-HIV activity, albeit through (a) so far unclear mechanism(s) of action [157].

In addition, a relatively large number of protease inhibitors have been isolated from the skin granular glands of various anuran species (reviewed in [158]). Given the impact of protease inhibitors on AIDS morbidity and mortality following their introduction [159], and their importance as second-line options in HAART combinations [147], anuran protease inhibitors may be of interest for developing novel antiHIV medications. This is particularly relevant when considering the unfavorable bioavailability and toxicity profile of available anti-HIV protease inhibitors [160], and their decreasing therapeutic efficacy due to the development of protease inhibitor-resistant HIV-1 [161].

\section{Urodela}

\section{Generalities about urodela}

The order Urodela (from the ancient Greek words 'uro' for 'tail' and 'dēlos' for 'conspicuous') or Caudata (Latin for 'tailed') consists of the salamanders, a group of slender, elongated amphibians with blunt snouts and short limbs projecting sideways, which have retained their laterally flattened fin-like tail as adults. Salamanders are in general

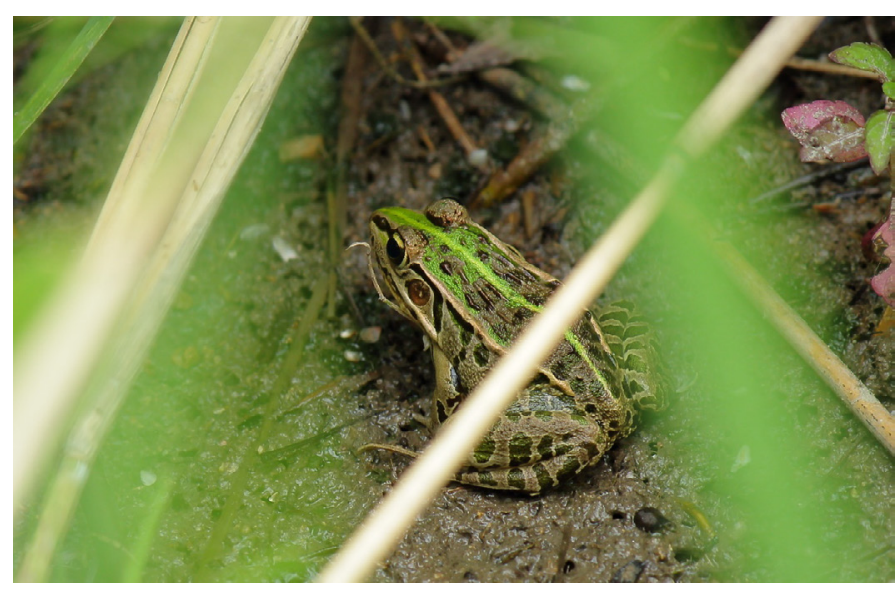

Figure 5. The Nagoya Daruma pond frog Rana brevipoda porsa (Ranidae) (https://images. app.goo.gl/RSWYbWzypbv4JmLd6) 
shorter than 15 centimeters and move close to the ground, bearing some similarity with lizards, but lack claws and have a smooth or warty skin without scutes or scales. These animals are mainly encountered in the non-tropical regions of the Northern hemisphere. Depending on the season, many species reside in terrestrial or freshwater habitats. As mentioned above, Anderson's salamander A. andersoni is one of the few species that lives in brackish or salt water [23].

One of the earliest salamanders on Earth was the extinct salamandroid Beiyanerpeton jianpingensis, fossilized remains of which dating from the Late Jurassic (about 155 million years ago) were found near the county town Jianping in the state of Beiyan in China [162]. Other archaeological finds in England and Kirghizstan (Central Asia) even date the Urodela to at least the Middle Jurassic, 174.1 to 163.5 million years ago [163]. These early species were the predecessors of the extant 754 species in 69 genera and 10 families [29]. The smallest is the terrestrial Veracruz pigmy salamander Thorius pennatulus (Plethodontidae) that can be found near Veracruz in Mexico and reaches a length of 15 to 21 millimeters [164]. The largest is the earlier mentioned fully aquatic Chinese giant salamander A. davidianus that can become as large as 1.8 meters [31].

The 10 Urodela families are assigned to three suborders, the Cryptobranchoidea, the Salamandroidea, and the Sirenoidea [29]. The suborder Cryptobranchoidea contains the primitive salamanders and includes, among others, the Chinese giant salamander A. davidianus and the hellbender C. alleganiensis [29]. The members of this group have retained several larval characteristics in their adult state such as gill slits and unlidded eyes, propagate by external fertilization, and breathe through lungs and the many folds in their thin skin [29]. The suborder Salamandroidea encompasses the evolutionary more advanced salamanders in, among others, the families Salamandridae (true salamanders as well as newts) and Plethodontidae (lungless salamanders which comprise about $70 \%$ of extant salamanders) [29]. The females of this suborder fertilize the eggs in their cloaca by spermatophores they have picked up after these have been deposited by males [29]. The suborder Sirenoidea includes eel-like aquatic salamanders with reduced forelimbs and no hind limbs which are classified into four species of sirens in a single family, the Sirenidae [29].

The development of salamanders is highly diverse, some species going through an elaborate metamorphosis while others, such as the axolotl Ambystoma mexicanum (Ambystomatidae) display pedomorphosis, retaining typical larval features such as external gills and a caudal fin extending from behind the head to the vent [29]. Due to their semiaquatic lifestyle as adults, alternating between aquatic and terrestrial habitats, newts in general do not undergo the dramatic developmental changes seen in other urodelnas [29].

Urodelans have also various strategies to their disposal for their defense against threats or attack. For instance, the larvae of mole salamanders in the genus Ambystoma (Ambystomatidae) delay hatching in the presence of predatory flatworms, allowing them to grow to more advanced stages which are more difficult to ingest by the worms [165]. And various adult salamanders produce sounds, adopt threatening poses, bite, and/or autotomize their tail in order to startle, intimidate, ward off or distract attackers, allowing them to escape [166-168].

In addition, like anurans, various urodelans produce mucus and toxins from their skin glands as a defense against predation [169]. The fire salamander S. salamandra is even able to squirt a fine jet of toxic fluid from the granular glands on its spine at an attacker from a distance of 80 centimeters [170]. The skin poisons are complex mixture of various ingredients including biogenic amines such as tryptamine and serotonine, proteins and peptides, steroids, most notably cholesterol, and unique steroidal alkaloids called salamander alkaloids or samandarines [169]. Some of these compounds are so poisonous that they can cause potentially lethal convulsions, even in larger animals and humans [171]. The skin toxins have also been used to taxonomically classify some urodelan taxa [172]. As seen in many toxic amphibian species, toxic salamanders such as the North American tiger salamander Ambystoma tigrinum (Ambystomatidae) and the fire salamander S. salamandra advertise their toxicity with striking aposematic skin coloration [170].

\section{Bioactive compounds from urodela}

The toxicity of Urodela, more specifically, salamanders, has been known since ancient times and has been subject of many fascinating myths and legends. The Roman author, naturalist, and natural philosopher Gaius Plinius Secundus, also known as Pliny the Elder (AD 23/24 - 79), has referred to salamanders as "the most wicked of all venomous animals" [173]. According to various tales, their skin secretions would poison the fruits of trees they had climbed in and would make the water of wells they had fallen into undrinkable, and their saliva would make the hair of human beings fall out [173]. Salamanders were also portrayed as products or even the origin of fire and, consequently, would be able to withstand heat and put out fires [173]. Indeed, it is with good reason that salamanders have extensively been used as weapons to attempt murder [173], as typical ingredients of magic potions of witches [173] and as a powerful symbol of alchemy [173]. This is illustrated in Shakespeare's Macbeth, in which the witches throw "the eyes of a newt and the toe of a frog" in their boiling cauldron [173].

On the other hand, salamanders also have long-standing medicinal uses. For example, a salamander crawling three times over a patient's clothing would treat fever or pain, a salamander carried by a patient in a special bag would treat wasting diseases, salamander skin placed on a woman's thigh would prevent pregnancy, and highly diluted salamander skin poison would treat epilepsy [169]. Even today, the Chinese giant salamander A. davidianus represents a luxury food item in China for nourishing the vital life force Qi, and is used in traditional Chinese medicine for treating, among others, neurasthenia, anemia, dysentery, and malaria [174]. Unfortunately, this has resulted in the decline of the wild population by more than $80 \%$ since the 1950 s, making this giant a critically endangered species [175]. Furthermore, salamander brandy that is supposedly indigenous to Slovenia and is prepared from the toxic skin secretions of live salamanders and alcohol, would cause extraordinary hallucinations and extreme sexual arousal [176].

Since some of the secretions from the granular glands have notable pharmacological properties which should be useful against human diseases. A few of them are addressed hereunder.

\section{Analgesic compounds}

One of the most deadly non-proteinaceous substances known to man is the quinazoline alkaloid tetrodotoxin, a neurotoxin in, among others, the skin secretions from the rough-skinned newt Taricha granulosa (Salamandridae) (Figure 6) from North America and other members of its genus [177]. Tetrodotoxins have been named after the Tetraodontiformes, an order of fish that includes, among others, pufferfish, globefish, blowfish, porcupinefish, and triggerfish in which they had first been identified $[178,179]$. The toxin also occurs in blueringed octopuses in the genus Hapalochlaena (Octopodidae), and 


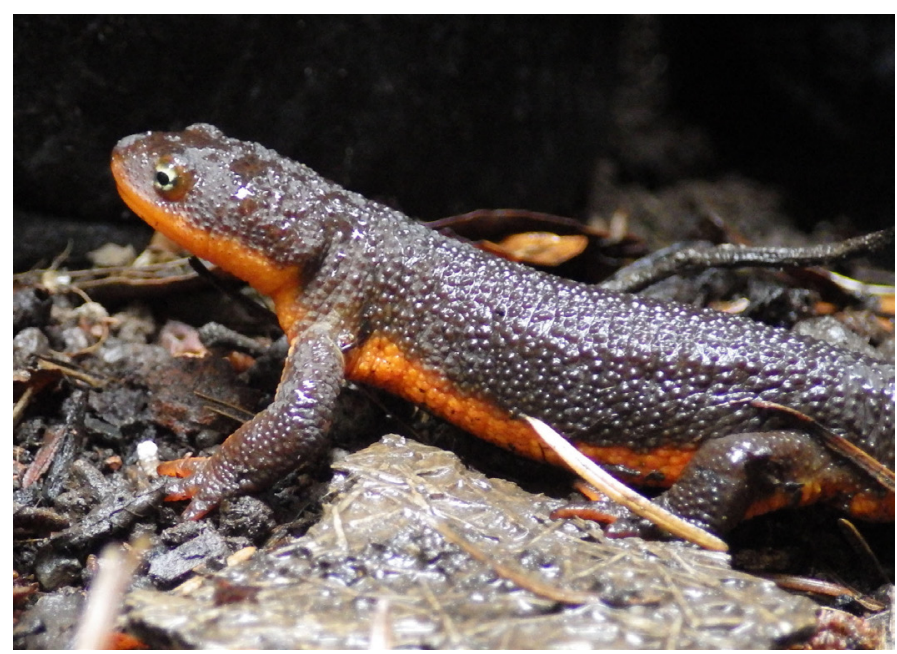

Figure 6. The rough-skinned newt Taricha granulosa (Salamandridae) (https://images.app. goo.gl/ZgWiZst7f39YdBhu6)

moon snails in the gastropode family Naticidae [178,179]. However, tetrodotoxin is neither produced by Taricha newt species nor by the other animal species but by certain bacteria that they consume, are infected with, or live symbiotically with such as Actinomyces, Aeromonas, Alteromonas, Bacillus, Pseudoalteromonas, Pseudomonas, and Vibrio species $[178,179]$. Despite its toxicity, a few predators such as the North American common garter snake Thamnophis sirtalis (Colubridae) are able to successfully prey on Taricha species because of their (partial) resistance to tetrodotoxin [180].

Tetrodotoxin selectively binds to the extracellular pore openings of fast voltage-gated sodium channels in nerve cell membranes [181]. This temporarily disables the function of the ion channels, blocking the passage of sodium ions into neurons and inhibiting the generation of action potentials in neurons [181]. As a result, the transmission of signals to produce muscle contractions is perturbed, which leads to loss of sensation and paralysis of voluntary muscles including the diaphragm and intercostal muscles and eventually death due to respiratory failure [181]. So far, there is no antidote for tetrodotoxin intoxication, therapy being limited to gastric lavage and/or respiratory support or mechanical ventilation until the toxin is completely excreted [182].

Because of its ability to block voltage-gated sodium channel and to cause paralysis, tetrodotoxin can potentially be applied as a pain relieving agent. This was already known to the ancient Chinese, who first used the toxic eggs from pufferfish about $2800 \mathrm{BC}$ to treat convulsive diseases [183]. Also, in Japanese traditional medicine, globefish was given in patients with leprosy in order to alleviate their neuralgia [183]. After the isolation and chemical characterization of tetrodotoxin from globefish ovaries in 1909 [183], this compound was used instead of parts of globe fish to suppress neuralgia associated with leprosy, and also to reduce muscle spasms due to tetanus and as an analgesic for patients with rheumatoid arthritis [183]. Tetrodotoxin has also been studied as a potential biological weapon on human subjects by Japan's infamous Unit 731, a covert biological and chemical warfare research and development unit of the Imperial Japanese Army that undertook lethal human experimentation during the Second Sino-Japanese War (1937-1945) of World War II [184].

The results on the potential efficacy of tetrodotoxin against neuropathic pain in cancer patients who do not respond to opioids and other analgesics were promising [179,185]. Although for unknown reasons not all patients responded, tetrodotoxin, given either intramuscularly or subcutaneously, elicited meaningful analgesic effects which lasted up to two weeks while toxicity was relatively mild [186188]. Other clinical studies have shown that tetrodotoxin may also help in reducing cue-induced increases in heroin craving and associated anxiety [189] and in alleviating acute heroin withdrawal syndrome [190] while causing relatively low side-effects [190].

Further clincial trials with tetrodotoxin for inadequately controlled pain related to cancer, against chemotherapy-induced peripheral neuropathy, to manage opiate withdrawal symptoms, and as a local anesthetic (see, for instance, [191]) have been suspended, since the results suggested that it did not meet the primary efficacy goal [192]. However, there are a number of good reasons to conduct further research on tetrodotoxin as a therapeutic agent: it does not cause myocardial depression like other local anesthetics [193]; hardly crosses the blood brain barrier, reducing the risk of seizures or central nervous system depression [194]; is not addictive like, for instance, opioids, which alter neurotransmitter levels [195]; and has long-lasting effects after being administered for a relatively short period of time [188].

\section{Antimicrobial compounds}

Apart from the quinazoline alkaloid tetrodotoxin, many members of the Salamandridae family (true salamanders and newts) produce steroidal alkaloids and secrete these compounds from their granular skin glands. Well-studied examples are the fire salamander $S$. salamandra (Figure 7) and the alpine salamander Salamandra atra in the skin secretions of which these compounds were first discovered [196-198]. The steroidal salamander alkaloids are called samandarines and have also been identified in other salamandrids such as such as the large alpine salamander S. lanzai, the bay Lycian salamander Lyciasalamandra billae, and the northern crested newt Triturus cristatus [199], and appeared to be the major compounds in their granular secretions [169]. In fact, samandarines are a unique class of steroidal alkaloids that are found nowhere else in nature but in the skin secretions of Salamandridae [197]. Furthermore, in contrast to the toxins of many other amphibians which are sequestered from their diet and symbiotic microorganisms [25,40], samandarines are biosynthesized by the salamanders themselves [196-198], probably from cholesterol as the starting material [198].

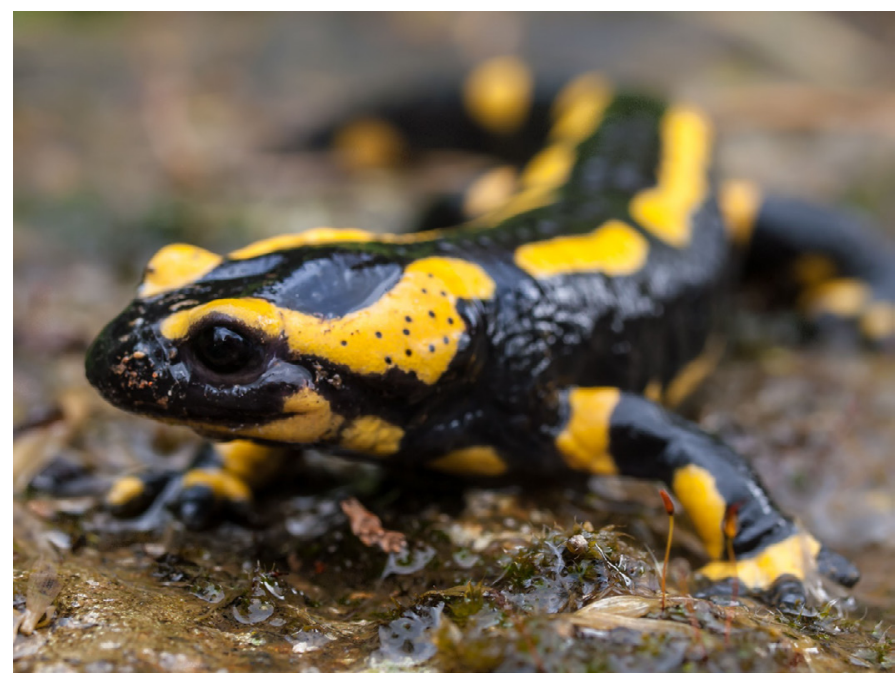

Figure 7. The fire salamander Salamandra salamandra (Salamandridae) (https://images. app.goo.gl/jcMZ9dqgGpBwXy1k9) 
Samadarines are neurotoxic compounds that mainly affect the spinal cord, and poisoning - through transdermal exposure or oral ingestion - can cause increased excitability of the medulla and hyperactivation of motoric elements, initially leading to overexcitation of the muscles and restlessness, hypertension, rapid breathing, dilated pupils, and increased secretion of mucus and saliva, and later to convulsions, dyspnea, and even death by respiratory paralysis $[169,199]$. The main samandarines are samandarine, samandarone and O-acetylsamandarine [169,199]; samandarine seems to be the most neurotoxic one, samandarone the least toxic $[36,197,198]$.

Apart from nerve-blocking and local anesthetic activities [169,199], the samandarines investigated today have shown antimicrobial activity. The crude cutaneous gland secretion of the near Eastern fire salamander Salamandra maculosa (Salamandridae) inhibited the growth of several gram-positive and -negative bacteria and fungi [200]. Furthermore, samandarine, samandarone, and samandaridine isolated from the skin gland secretions of this salamander species elicited a more or less specific bactericidal and/or fungicidal activity [201]. The toxins caused signs of lysis in the cytoplasm and the plasma membrane of the baker's yeast Saccharomyces cerevisiae (Saccharomycetaceae) [201]. Notably, from the individual compounds tested, samandarone was active against the broadest range of microorganisms and displayed the strongest antimicrobial activity [201]. In a more recent study, the partially purified skin secretions from the smooth newt Lissotriton vulgaris (Salamandridae) and the Balkan crested newt Triturus ivanbureschi (Salamandridae) also showed broad in vitro antimicrobial activity, including activity against antibiotic-resistant bacterial strains [202].

Unfortunately, the samandarines evaluated today were not better than most currently available antibiotics, showing activity at concentrations around $10 \mu \mathrm{M}$ [201]. For this reason, there are currently no therapeutic uses for samandarins. However, it is conceivable that using modern structure-activity relationship techniques, combinatorial chemistry strategies, and high-throughput screening approaches, analogues can be developed with less toxicity and clinically more useful features.

\section{Gymnophiona}

\section{Generalities about gymnophiona}

The order Gymnophiona or Apoda comprises the caecilians, which are readily distinguished from the Anura and the Urodela by their elongated, cylindrical, legless and nearly tail-less body which make them look somewhat like snakes or worms. This resemblance is captured in the names of this amphibian order, 'gymnos' and 'ophis' meaning 'naked' and 'serpent', respectively, in ancient Greek, and ' $a$ ' and 'poda' standing for 'without' and 'legs', respectively. However, the oldest known caecilian, the extinct Eocaecilia micropodia dating from the early Jurassic period, roughly 200 million years ago [203], had short legs reminiscent of its tetrapod origin. The extant Gymnophiona consist of about 256 species in 56 genera and 10 families, comprising the smallest order of the amphibians [29]. The tiniest species is the Makumunu Assumbo caecilian Idiocranium russeli (Indotyphlidae) from Cameroon that reaches a length of at the most 9 centimeters [204]. The largest is Thompson's caecilian Caecilia thompsoni (Caeciliidae) that is endemic to Colombia and can become 1.5 meters long and can weigh 1 kilogram [205].

Gymnophiona have in general rudimentary eyes, and are mostly encountered in the tropical regions of Africa, Asia, as well as Central and South America, where they spend most of their life underground in damp soil, among rotten wood, and under plant debris [29]. The main exceptions are the aquatic caecilians or rubber eels in the family Typhlonectidae, which inhabit semi-aquatic or aquatic environments in the northern parts of South America [29]. The ten families are distinguished from one another by the presence or absence of a tail, the degree of fusion of cranial bones, the degree of kineticism of the skull, the nature of the annular grooves, and the structure of the phallodeum, a penis-like appendage in males [29].

Gymnophiona are the only order of amphibians that exclusively uses internal insemination: the male inserts its phallodeum into the cloaca of the female for mating sessions that can last two to three hours [206]. About $75 \%$ of caecilians - either aquatic or terrestrial - are viviparous, giving birth to already-developed offspring [207,208]. Certain viviparous caecilians feed their offspring by maternal dermophagy, involving the mother producing a nutritious outer layer of its skin or its uterine for her young to feed on by scraping with their distinctive teeth, with multiple cusps [209]. The remaining $25 \%$ are oviparous and lay their eggs in burrows in mud that is close to water [208]. The eggs hatch into free-swimming larvae which have large, leaf-like gills that are resorbed at metamorphosis [208]. Oviparous caecilians can also lay their eggs terrestrially, which hatch into miniature versions of the adult form, skipping the free-swimming larval stage [208]. In fact, most caecilians do not undergo an anuran-like metamorphosis [210].

The skin of Gymnophiona has numerous ring-shaped folds or annuli that partially encircle the body, giving the animals a segmented appearance. In some species of caecilian, the skin bears calcite scales which are not seen in other Lissamphibia [211]. So far, only a limited number have been evaluated for their skin content, but currently available data suggest that most caecilians are toxic to predators [212]. Many toxic species have a purple-, green-, blue-, orange-, and/ or yellow-colored skin (in contrast to the gray, brown, or black skin of most non-toxic species) which probably serves as an aposematic warning to predators [213].

\section{Bioactive compounds from gymnophonia}

Due to the reclusive lifestyle of Gymnophonia, studies on the bioactive compounds in their skin secretions have so far been limited to a few reports with relatively little focus on the pharmacological activities of the (ingredients in the) substances. For instance, the granular secretion of the common yellow-banded caecilian Ichthyophis glutinosus (Ichthyophiidae) from Sri Lanka reportedly contained toxic compounds which would repel potential predators [214], but this was not in agreement with a previous study [215] reporting that it is not venomous. The Cayenne caecilian Typhlonectes compressicauda (Typhlonectidae) that lives in the Amazon basin and river systems in the Guianas, also produces toxic mucus in slime glands all over its body which it readily secretes when attacked [216]. In a feeding experiment, this secretion was found to be strongly irritating to the human eye and lethal to the predatory wolf fish [216], but no further pharmacological and biochemical studies have been done on this substance.

More comprehensive studies have been carried out with the skin secretion of Boettger's caecilian Siphonops paulensis (Siphonopidae). This substance exerted hemolytic activity $[217,218]$ and also caused indirect cardiotoxic activity in in situ toad heart preparations by increasing $\mathrm{K}^{+}$concentration of the medium [217,219]. Furthermore, treatment of an artificial lipid bilayer with this substance led to the formation of voltage-dependent channels in the membrane [220]. However, the clinical significance of these findings is not clear at this moment. 


\section{Antiparasitic compounds}

Interesting and potentially clinically applicable results on pharmacologically active compounds from Gymnophiona were obtained with the ringed caecilian Siphonops annulatus (Figure 8) (Siphonopidae). This creature occupies a broad diversity of ecosystems throughout South America [29]. The skin secretion of this animal elicited meaningful antiparasitic activity against cultured promastigotes of Leishmania (Leishmania) infantum (also known as L. (L.) chagasi) and trypomastigotes of Trypanosoma cruzi [221]. These activities could be localized to a hydrophobic fraction and were better than those caused by the standard drugs miltefosine and benznidazole, respectively [221]. However, the S. annulatus skin secretion was not active against amastigotes of $L$. (L.) infantum and displayed excessive cytotoxicity against normal peritoneal murine macrophages [221].

Nevertheless, this study may have merit, since $L$. (L.) infantum) is an important causative agent of visceral leishmaniasis, a slow but progressive illness and the most severe form of leishmaniasis that is invariably fatal if left untreated [222]. More than $90 \%$ of cases (about 300,000 per year) occur in India, Bangladesh, Nepal, Sudan, and Brazil, and the worldwide mortality has been estimated at 20,000 to 40,000 [222]. T. cruzi is responsible for causing Chagas disease (also known as American trypanosomiasis), a tropical disease that is mostly spread by blood-sucking triatomine bugs tend (also called kissing bugs because they tend to bite people's faces [223]. An estimated 8 million people in Mexico, Central America, and South America have Chagas disease, most of whom do not know they are infected. However, if untreated, infection is lifelong and can be life-threatening, particularly because of cardiac complications which can include an enlarged heart, heart failure, altered heart rate or rhythm, and cardiac arrest [223].

The S. annulatus skin secretion had been called 'siphonopsina' [224]. Initial studies indicated that they contain serotonin and bufotenine [225]. So far, however, the role of these compounds in the antiparasitic activity of the secretions is not clear. There are also no clear indications about the chemical structure(s) of the actual pharmacologically active ingredient(s).

\section{Conclusion}

Secretions from their grandular skin glands comprise important defense of amphibians against attack by all kinds of microorganisms, parasites, and large predators. The pharmacological activities of their

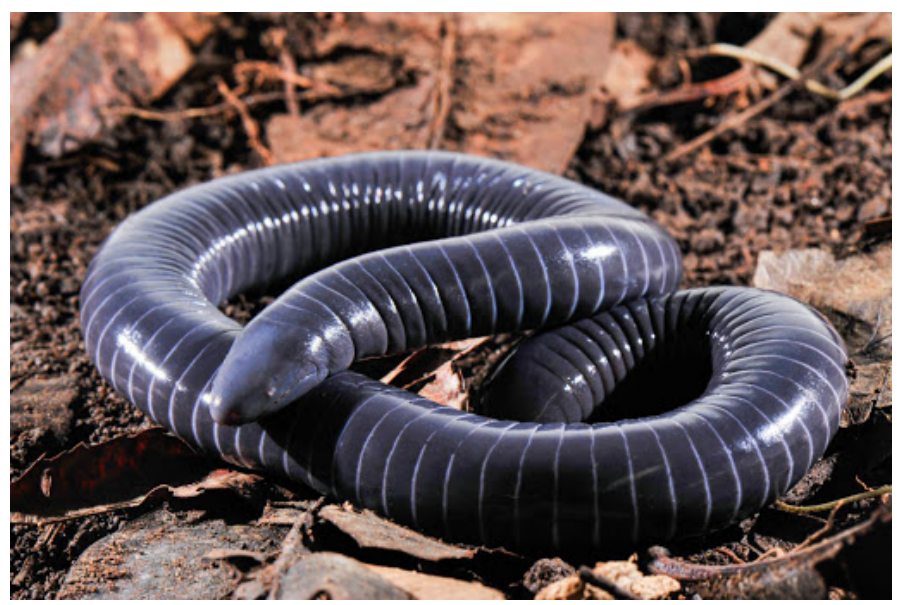

Figure 8. The ringed caecilian Siphonops annulatus (Siphonopidae) (https://images.app. goo.gl/EPAD9U4QNbDoq4ZD9) ingredients have been refined during 370 million years of evolution. Thus, these substances may represent extraordinarily rich sources of bioactive compounds for developing novel medications including medications against these diseases. This paper has extensively reviewed a few compounds from anurans, urodelans, and gymnophiones which may lead to the development of novel and improved medications for treating Alzheimer's disease, a failing heart, diabetes mellitus, HIV/ AIDS, chronic pain, as well as micriobial and parasitic infections. Notably, a relatively large proportion of amphibians (particularly the reclusive Gymnophonia) has not even been explored for pharmacologically active compounds, while new species are being discovered on a regulalar basis [29]. Thus, there is high probability that further exploration of this class of animals will help identify many lead compounds for developing novel therapeutics. That this approach may pay off, is illustrated by the alkaloid epibatidine from the skin of the phantasmal poison frog Epipedobates tricolor (Dendrobatidae), a species of poison dart frog that is endemic to Ecuador (South America) [226]. Epibatidine has led to the development of a novel class of nonopioid painkillers with a potency ranging of 100 - to 200 -fold that of the analgesic opioid morphine and 30 times that of nicotine while not being addictive [227]. Unfortunately, its very narrow therapeutic index has prohibited its use in humans [227]. This has led to the synthesis of a number of epibatine analogs that retain the superior analgesics effects but do not cause the toxicity (see, for instance, [228]), and hopefully may someday provide a clinically useful compound.

In the mean time, it should be kept in mind that many amphibians including E. tricolor obtain their toxins through their diet and do not produce them in captivity $[25,40]$. However, a relatively recent assessment suggests that at least 3,000 of the roughly 8,000 species of amphibian species throughout the world are threatened with extinction [229]. This poses an urgent need to implement proper in situ conservation strategies in order to protect these creatures before it is too late. At the same time, their glandular skin secretions should thoroughly be evaluated for the presence of effective, novel lead structures using advanced high-throughput screening techniques. When considering the experience with other more comventional sources of novel drugs such as plants and microorganisms, these approaches are virtually guaranteed to produce improved therapeutics with novel structures and unique mechanisms of action.

\section{References}

1. Mans DRA (2013) From forest to pharmacy: plant-based traditional medicines as sources for novel therapeutic compounds. Acad J Med Plants 1: 101-110.

2. Breckenridge A (2006) William Withering's legacy - for the good of the patient. Clin Med (Lond) 6: 393-397.

3. Hadden DR (2005) Goat's rue - French lilac - Italian fitch - Spanish sainfoin: Gallega officinalis and metformin: the Edinburgh connection. $J$ R Coll Physicians Edinb 35: 258-260.

4. Tong WY, Dong X (2009) Microbial biotransformation: recent developments on steroid drugs. Recent Pat Biotechnol 3: 141-153.

5. Van Der Heijden R, Jacobs DI, Snoeijer W, Hallard D, Verpoorte R (2004) The Catharanthus alkaloids: pharmacognosy and biotechnology. Curr Med Chem 11: 607628 .

6. Seltzer B (2010) Galantamine-ER for the treatment of mild-to-moderate Alzheimer's disease. Clin Interv Aging 5: 1-6. [Crossref]

7. Demain AL, Elander RP (1999) The beta-lactam antibiotics: past, present, and future. Antonie Van Leeuwenhoek 75: 5-19.

8. Abastado P (2006) $20^{\text {th }}$ century at a glance: the streptomycin story. Med Sci (Paris) 22: $544-547$.

9. Kumar CG, Himabindu M, Jetty A (2008) Microbial biosynthesis and applications of gentamicin: a critical appraisal. Crit Rev Biotechnol 28: 173-212. 
10. Caffrey P, Lynch S, Flood E, Finnan S, Oliynyk M (2001) Amphotericin biosynthesis in Streptomyces nodosus: deductions from analysis of polyketide synthase and late genes. Chem Biol 8: 713-723.

11. Zhang D, Zhao L, Wang L, Fang X, Zhao J, et al. (2017) Griseofulvin derivative and indole alkaloids from Penicillium griseofulvum CPCC 400528. J Nat Prod 80: 371-376.

12. Gerwick WH, Moore BS (2012) Lessons from the past and charting the future of marine natural products drug discovery and chemical biology. Chem Biol 19: 85-98.

13. Rinehart KL (2000) Antitumor compounds from tunicates. Med Res Rev 20: 1-27. [Crossref]

14. Mir R, Karim S, Kamal MA, Wilson CM, Mirza Z (2016) Conotoxins: structure, therapeutic potential and pharmacological applications. Curr Pharm Des 22: 582-589.

15. Vane JR (1999) The history of inhibitors of angiotensin-converting enzyme. J Physiol Pharmacol 50: 489-498.

16. Mans DRA, Sairras S, Ganga D, Kartopawiro J (2016) Exploring the global animal biodiversity in the search for new drugs - Insects. J Transl Sci 3: 371-386.

17. Mans DRA (2017) Exploring the global animal biodiversity in the search for new drugs - chelicerates, myriapods, and crustaceans. J Transl Sci 3: 1-18.

18. Clack JA (2007) Devonian climate change, breathing, and the origin of the tetrapod stem group. Integr Comp Biol 47: 510-523.

19. Pierce S, Clack J, Hutchinson J (2012) Three-dimensional limb joint mobility in the early tetrapod Ichthyostega. Nature 486: 523-526. [Crossref]

20. Sahney S, Benton MJ, Falcon-Lang HJ (2010) Rainforest collapse triggered Carboniferous tetrapod diversification in Euramerica. Geology 38: 1079-1082.

21. Maxwell WD (1992) Permian and Early Triassic extinction of non-marine tetrapods. Palaeontology 35: 571-583

22. Wostl E, Smith EN, Reed RN (2016) Origin and identity of Fejervarya (Anura: Dicroglossidae) on Guam. Pac Sci 70: 233-241.

23. Krebs SL, Brandon RA (1984) A new species of salamander (Family Ambystomatidae) from Michoacan, Mexico. Herpetologica: 238-245.

24. Relyea RA (2005) The lethal impact of Roundup on aquatic and terrestrial amphibians. Ecol Appl 15: 1118-1124.

25. Toledo RC, Jared C (1995) Cutaneous granular glands and amphibian venoms. Comp Biochem Physiol I: 1-29.

26. Vences M, Kosuch J, Boistel R, Haddad CFB, La Marca E, et al. (2003) Convergent evolution of aposematic coloration in neotropical poison frogs: a molecular phylogenetic perspective. Org Divers Evol 3: 215-226. [Crossref]

27. Brown DD, Cai L (2007) Amphibian metamorphosis. Dev Biol 306: 20-33.

28. Newman RA (1992) Adaptive plasticity in amphibian metamorphosis. BioScience 42: 671-678.

29. AmphibiaWeb (2020) University of California, Berkeley, CA, USA. Downloaded from https://amphibiaweb.org . Accessed June 8, 2020.

30. Rittmeyer EN, Allison A, Gründler MC, Thompson DK, Austin CC (2012) Ecological guild evolution and the discovery of the world's smallest vertebrate. PLoS One 7: e29797.

31. Yan F, Lü J, Zhang B, Yuan Z, Zhao H, et al. (2018) The Chinese giant salamander exemplifies the hidden extinction of cryptic species. Curr Biol 28: R590-R592. [Crossref]

32. Cox CB, Hutchinson P (1991) Fishes and amphibians from the Late Permian Pedra de Fogo Formation of Northern Brazil. Palaeontology 34: 561-573.

33. Hoffman CW, Dent JN (1978) Morphology of mucous gland and its responses to prolactin in the skin of the red spotted newt. J Morphol 157: 79-97.

34. Wanninger M, Schwaha T, Heiss E (2018) Form and function of the skin glands in the Himalayan newt Tylototriton verrucosus. Zool Lett 4: 15.

35. Barthalmus GT, Zielinski WJ (1988) Xenopus skin mucus induces oral dyskinesias that promote escape from snakes. Pharmacol Biochem Behav 30: 957-959.

36. Daly JW, Spade TF, Garaffo HM (2005) Alkaloids from amphibian skin: a tabulation of over eight-hundred compounds. J Nat Prod 68: 1556-1575.

37. Varga JFA, Bui-Marinos MP, Katzenback BA (2019) Frog skin innate immune defences: sensing and surviving pathogens. Front Immunol 9: 3128. [Crossref]
38. Brandon RA, Labanick GM, Huheey JE (1979) Relative palatability, defensive behavior, and mimetic relationships of red salamanders (Pseudotriton ruber), mud salamanders (Pseudotriton montanus), and red efts (Notophthalmus viridescens). Herpetologica 35: 289-303.

39. Rinaldi AC (2002) Antimicrobial peptides from amphibian skin: an expanding scenario. Curr Opin Chem Biol 6: 799-804.

40. Lasley EN (1999) Having their toxins and eating them too: study of the natural sources of many animals' chemical defenses is providing new insights into nature's medicine chest. BioScience 49: 945-950.

41. Daly JW, Garraffo HM, Pannell LK, Spande TF (1990) Alkaloids from Australian frogs (Myobatrachidae): pseudophrynamines and pumiliotoxins. J Nat Prod 53: 401-421.

42. Von Byern J, Mebs D, Heiss E, Dicke U, Wetjen O, et al. (2017) Salamanders on the bench: a biocompatibility study of salamander skin secretions in cell cultures. Toxicon 135: 24-32.

43. Summers K, Clough ME (2001) The evolution of coloration and toxicity in the poison frog family (Dendrobatidae). Proc Natl Acad Sci USA 98: 6227-6232.

44. Santos JC, Coloma LA, Cannatella DC (2003) Multiple, recurring origins of aposematism and diet specialization in poison frogs. Proc Natl Acad Sci USA 100: 12792-12797.

45. Beukema W, Nicieza AG, Lourenco A, Velo-Anton G (2016) Colour polymorphism in Salamandra salamandra (Amphibia: Urodela), revealed by a lack of genetic and environmental differentiation between distinct phenotypes. J Zool Syst Evol Res 54 127-136.

46. Darst CR, Cummings ME (2006) Predator learning favours mimicry of a less-toxic model in poison frogs. Nature 440: 208-211.

47. Garg AD, Hippargi R, Gandhare AN (2008) Toad skin-secretions: potent source of pharmacologically and therapeutically significant compounds. Internet J Pharmacol 5: 17 .

48. Sabater-Pi J (1985) Contribution to the biology of the giant frog (Conraua goliath, Boulenger). Amphibia-Reptilia 6: 143-153.

49. Ascarrunz E, Rage J-C, Legreneur P, Laurin M (2016) Triadobatrachus massinoti, the earliest known lissamphibian (Vertebrata: Tetrapoda) re-examined by $\mu \mathrm{CT}$-scan, and the evolution of trunk length in batrachians. Contrib Zool 58: 201-234.

50. Roček Z (2000) Mesozoic amphibians. In: Heatwole H, Carroll RL (eds) Amphibian Biology 4. Palaeontology: the evolutionary history of amphibians. Surrey Beatty \& Sons, Chipping Norton, NSW, Australia.

51. Carvajal-Castro JD, López-Aguirre Y, Ospina-L AM, Santos JC, Rojas B, et al. (2020) Much more than a clasp: evolutionary patterns of amplexus diversity in anurans. Biol J Linn Soc 129: 652-663.

52. Galton VA (1992) The role of thyroid hormone in amphibian metamorphosis. Trends Endocrinol Metab 3: 96-100.

53. Warkentin KM, Currie CR, Rehner SA (2001) Egg-killing fungus induces early hatching of red-eyed treefrog eggs. Ecology 82: 2860-2869.

54. Toledoa LF, Sazima I, Haddad CFB (2010) Is it all death feigning? Case in anurans. $J$ Nat Hist 44: 1979-1988.

55. Wente WH, Phillips JB (2003) Fixed green and brown color morphs and a novel colorchanging morph of the Pacific tree frog Hyla regilla. Am Nat 162: 461-473. [Crossref]

56. Baldo ECF, Anjolette FAP, Arantes EC, Baldo MA (2015) Toad poison and drug discovery. In: Gopalakrishnakone P (eds) Toxins and drug discovery. Toxinology. Springer, Dordrecht, The Netherlands.

57. Daly JW, Secunda S, Garraffo HM, Spande TF, Wisnieski A, et al. (1994) An uptake system for dietary alkaloids in poison frogs (Dendrobatidae). Toxicon 32: 657-663.

58. Jones TH, Gorman JST, Snelling RR, Delabie JHC, Blum MS, et al. (1999) Further alkaloids common to ants and frogs: decahydroquinolines and a quinolizidine. $J C h e m$ Ecol 25: 1179-1193.

59. Daly JW, Kaneko T, Wilham J, Garraffo HM, Spande TF, et al. (2002) Bioactive alkaloids of frog skin: combinatorial bioprospecting reveals that pumiliotoxins have an arthropod source. Proc Natl Acad Sci USA 99: 13996-14001.

60. Saporito RA, Donnelly MA, Hoffman RL, Garraffo HM, Daly JW (2003) A siphonotid millipede (Rhinotus) as the source of spiropyrrolizidine oximes of dendrobatid frogs. $J$ Chem Ecol 29: 2781-2786. 
61. Saporito RA, Garraffo HM, Donnelly MA, Edwards AL, Longino JT, et al. (2004) Formicine ants: an arthropod source for the pumiliotoxin alkaloids of dendrobatid poison frogs. Proc Natl Acad Sci USA 101: 8045-8050. [Crossref]

62. Liang FE, Changyuan YE, Jianping J (2015) Progress and prospects for studies on Chinese amphibians. Asian Herpetol Res 1: 64-85.

63. Zipes J (2016) The original folk and fairy tales of the Brothers Grimm: the complete first edition. Princeton University Press, Princeton, UK.

64. Rodríguez C, Rollins-Smith L, Ibáñez R, Durant-Archibold A, Gutiérrez M (2016) Toxins and pharmacologically active compounds from species of the family Bufonidae (Amphibia, Anura). J Ethnopharmacol 198: 235-254.

65. Way EL, Liu YQ, Chen CF (1996) Perspective and overview of Chinese traditional medicine and contemporary pharmacology. In: Jucker E (ed) Progress in Drug Research/ Fortschritte der Arzneimittelforschung/Progrès des recherches pharmaceutiques. Progress in Drug Research/Fortschritte der Arzneimittelforschung/Progrès des recherches pharmaceutiques, vol 47. Birkhäuser, Basel, Switzerland.

66. Huang KC (1993) The pharmacology of Chinese herbs. CRC Press, Boca Raton (FL), USA.

67. Meng Z, Yang P, Shen Y, Bei W, Zhang Y, et al. (2009) Pilot study of huachansu in patients with hepatocellular carcinoma, non-small-cell lung cancer, or pancreatic cancer. Cancer 115: 5309-5318.

68. Xie X, Huang X, Li J, Lv X, Huang J, et al. (2013) Efficacy and safety of Huachansu combined with chemotherapy in advanced gastric cancer: a meta-analysis. Med Hypotheses 81: 243-250.

69. Daly JW, Padgett WL, Saunders RL, Cover JF Jr (1997) Absence of tetrodotoxins in a captive-raised riparian frog, Atelopus varius. Toxicon 35: 705-709.

70. Yotsu-Yamashita M, Kim YH, Dudley SC, Choudhary G, Pfahnl A, et al. (2004) The structure of zetekitoxin $\mathrm{AB}$, a saxitoxin analog from the Panamanian golden frog Atelopus zeteki: a potent sodium-channel blocker. Proc Natl Acad Sci USA 101: 43464351.

71. Yotsu-Yamashita M, Tateki E (2010) First report on toxins in the Panamanian toads Atelopus limosus, A. glyphus and A. certus. Toxicon 55: 153-156.

72. Xin XL, Zhang BJ, Su DH, Deng S, Huang SS, et al. (2012) Pharmacology advances in studies on Bufo Bufo Gargarizans. Prog in Mod Biomed 12: 588-590, 600.

73. Yang Q, Zhou X, Zhang M, Bi L, Miao S, et al. (2015) Angel of human health: current research updates in toad medicine. Am J Transl Res 7: 1-14. [Crossref]

74. Gao F, Wang X, Li Z, Zhou A, Tiffany-Castiglioni E, et al. (2017) Identification of antitumor components from toad venom. Oncol Lett 14: 15-22.

75. Csordás AH, Michl H (1970) Isolation and structure of a haemolytic polypeptide from the defensive secretion of European Bombina species. Monatsh Chem 101: 182-189.

76. Zasloff M (1987) Magainins, a class of antimicrobial peptides from Xenopus skin: isolation, characterization of two active forms, and partial cDNA sequence of a precursor. Proc Natl Acad Sci USA 84: 5449-5453.

77. Mor A, Nguyen VH, Delfour A, Migliore-Samour D, Nicolas P (1991) Isolation, amino acid sequence, and synthesis of dermaseptin, a novel antimicrobial peptide of amphibian skin. Biochemistry 30: 8824-8830.

78. Gibson BW, Tang DZ, Mandrell R, Kelly M, Spindel ER (1991) Bombinin-like peptides with antimicrobial activity from skin secretions of the Asian toad, Bombina orientalis. J Biol Chem 266: 23103-23111.

79. Simmaco M, Barra D, Chiarini F, Noviello L, Melchiorri P, et al. (1991) A family of bombinin-related peptides from the skin of Bombina variegata. Eur J Biochem 199: 217-222.

80. Morikawa N, Hagiwara K, Nakajima T (1992) Brevinin-1 and -2, unique antimicrobial peptides from the skin of the frog, Rana brevipoda porsa. Biochem Biophys Res Commun 189: 184-190.

81. Suzuki S, Ohe Y, Okubo T, Kakegawa T, Tatemoto K (1995) Isolation and characterization of novel antimicrobial peptides, rugosin A, B and C, from the skin of the frog, Rana rugosa. Biochem Biophys Res Commun 212: 249-254.

82. Qi J, Zulfiker AHM, Li C, Good D, Wei MQ (2018) The development of toad toxins as potential therapeutic agents. Toxins (Basel) 10: 336

83. Scheltens P, Blennow K, Breteler MM, de Strooper B, Frisoni GB, et al. (2016) Alzheimer's disease. Lancet 388: 505-517.

84. World Health Organization (2019) Dementia. Downloaded from: https://www.who.int/ news-room/fact-sheets/detail/dementia. Accessed July 24, 2020.
85. Dubois B, Feldman HH, Jacova C, Hampel H, Molinuevo JL, et al. (2014) Advancing research diagnostic criteria for Alzheimer's disease: the IWG-2 criteria. Lancet Neurol 13: 614-629.

86. Stanciu GD, Luca A, Rusu RN, Bild V, Beschea Chiriac SI, et al. (2019) Alzheimer's disease pharmacotherapy in relation to cholinergic system involvement. Biomolecules 10: 40 .

87. Hanseeuw BJ, Betensky RA, Jacobs HIL, Schultz AP, Sepulcre J, et al. (2019) Association of amyloid and tau with cognition in preclinical Alzheimer disease. JAMA Neurol 76: 915-924.

88. Ismail R, Parbo P, Madsen LS, Hansen AK, Hansen KV, et al. (2020) The relationships between neuroinflammation, beta-amyloid and tau deposition in Alzheimer's disease: longitudinal PET study. J Neuroinflammation 17: 151.

89. Weller J, Budson A (2018) Current understanding of Alzheimer's disease diagnosis and treatment.

90. Yiannopoulou KG, Papageorgiou SG (2020) Current and future treatments in Alzheimer Disease: an update. J Cent Nerv Syst Dis 12: 1179573520907397. [Crossref]

91. Sharma K (2019) Cholinesterase inhibitors as Alzheimer's therapeutics (Review). Mol Med Rep 20: 1479-1487.

92. Spinelli R, Aimaretti FM, López JA, Siano AS (2019) Amphibian skin extracts as source of bioactive multi-target agents against different pathways of Alzheimer's disease. Nat Prod Res 1-4.

93. Spinelli R, Sanchis I, Aimaretti FM, Attademo AM, Portela M, et al. (2019) Natural multi-target inhibitors of cholinesterases and monoamine oxidase enzymes with antioxidant potential from skin extracts of Hypsiboas cordobae and Pseudis minuta (Anura: Hylidae). Chem Biodiver 16: e1800472.

94. Siano ÁS (2011) Péptidos antimicrobianos naturales y sintéticos de pieles de anfibios. Potenciales aplicaciones en salud humana [Natural and synthetic antimicrobial peptides from the skin of amphibians. Potential applications for human health]. Doctoral thesis. National University of Litoral, Faculty of Biochemistry and Biological Sciences, Santa $\mathrm{Fe}$, Argentina.

95. Siano A, Gatti PI, Imaz MS, Zerbini E, Simonetta AC, et al. (2014) A comparative study of the biological activity of skin and granular gland secretions of Leptodactylus latrans and Hypsiboas pulchellus from Argentina. Rec Nat Prod 8: 128-135.

96. Sanchis I, Spinelli R, Aschemacher N, Humpola MV, Siano A (2020) Acetylcholinesterase inhibitory activity of a naturally occurring peptide isolated from Boana pulchella (Neobatrachia: Hylidae) and its analogs. Amino Acids 52: 387-396.

97. Siano A, Húmpola MV, de Oliveira E, Albericio F, Simonetta AC, et al. (2014) Antimicrobial peptides from skin secretions of Hypsiboas pulchellus (Anura: Hylidae) J Nat Prod 77: 831-841.

98. Siano A, Garibotto FF, Andujar SA, Baldoni HA, Tonarelli GG, et al. (2017) Molecular design and synthesis of novel peptides from amphibian skin acting as inhibitors of cholinesterase enzymes. J Pept Sci 23: 236-244.

99. Tan LB, Williams SG, Tan DK, Cohen-Solal A (2010) So many definitions of heart failure: are they all universally valid? A critical appraisal. Expert Rev Cardiovasc Ther 8: 217-228. [Crossref]

100. Lippi G, Sanchis-Gomar F (2020) Global epidemiology and future trends of heart failure. $A M E$ Med J 5: 15

101. Whayne Jr TF (2018) Clinical use of digitalis: a state of the art review. Am $J$ Cardiovasc Drugs 18: 427-440.

102. Choi HM, Park MS, Youn JC (2019) Update on heart failure management and future directions. Korean J Intern Med 34: 11-43.

103. Morishita S, Shoji M, Oguni Y, Ito C, Noguchi K, et al. (1991) Congestive heart failure model in rabbits: effects of digoxin and a drug containing toad venom. Jpn J Pharmacol 56: 427-432.

104. Ojiri Y, Noguchi K, Sakanashi M (1991) Effects of a senso (toad venom) containing drug on systemic hemodynamics, cardiac function and myocardial oxygen consumption in anesthetized dogs. Am J Chin Med 19: 17-31.

105. Morishita A, Shoji M, Oguni Y, Ito C, Noguchi K, et al. (1992) Effects of "kyushin", a drug-containing toad venom, on experimental congestive heart failure in rabbits. Am J Chin Med 20: 83-89.

106. Morishita S, Shoji M, Oguni Y, Ito C, Higuchi M, et al. (1992) Pharmacological actions of "kyushin," a drug-containing toad venom: cardiotonic and arrhythmogenic effects, and excitatory effect on respiration. Am J Chin Med 20: 245-256. 
107. Sakanashi M, Noguchi K, Chibana T, Ojiri Y, Shoji M (1993) Effects of intraduodenal administration of "kyushin," a senso (toad venom)-containing drug, on systemic hemodynamics, cardiac function and myocardial oxygen consumption in anesthetized dogs. Am J Chin Med 21: 7-16.

108. Ojiri Y, Chibana T, Noguchi K, Sakanashi M (1992) Cardiovascular effect of a senso (toad venom)-containing drug in anesthetized dogs (2): influence of propranolol. $\mathrm{Am}$ J Chin Med 20: 147-155.

109. Shoji M, Oguni Y, Sato H, Morishita S, Ito C, et al. (1993) Pharmacological actions of "kyushin," a drug containing toad venom (2): effects on urinary volume and electrolyte excretion. Am J Chin Med 21: 17-31. [Crossref]

110. Morishita S, Sugimoto C, Shoji M, Hirai Y, Oguni Y, et al. (1993) Pharmacological actions of "kyushin," a drug containing toad venom (3): effects on experimentally induced arrhythmia. Am J Chin Med 21: 139-149.

111. Yamahara J, Tanaka S, Matsuda H, Sawada T, Fujimura H (1986) The mode of cardiac action of cardiotonic steroids isolated from toad cake in perfused working guinea-pig heart and effect of cinobufagin on experimental heart failure. Nihon Yakurigaku Zasshi 88: 413-423.

112. Pamnani MB, Chen S, Bryant HJ, Schooley JF Jr, Eliades DC, et al. (1991) Effects of three sodium-potassium adenosine triphosphatase inhibitors. Hypertension 18: 316-324.

113. Hirai Y, Morishita S, Ito C, Sakanashi M. (1992) Effects of bufadienolides and some kinds of cardiotonics on guinea pig hearts. Nihon Yakurigaku Zasshi 100: 127-135.

114. Matsukawa M, Akizawa T, Morris JF, Butler VP Jr, Yoshioka M (1996) Marinoic acid, a novel bufadienolide-related substance in the skin of the giant toad, Bufo marinus. Chem Pharm Bull (Tokyo) 44: 255-257.

115. Matsukawa M, Akizawa T, Ohigashi M, Morris JF, Butler VP Jr, et al. (1997) A novel bufadienolide, marinosin, in the skin of the giant toad, Bufo marinus. Chem Pharm Bull (Tokyo) 45: 249-254.

116. Okur ME, Karantas ID, Siafaka PI (2017) Diabetes mellitus: a review on pathophysiology, current status of oral medications and future perspectives. Acta Pharm Sci 55: 61-82.

117. International Diabetes Federation (2019) IDF Diabetes Atlas, $9^{\text {th }}$ ed. Brussels, Belgium. Downloaded from https://www.diabetesatlas.org. Accessed July 22, 2020.

118. Wang C-Y, Neil DL, Home P (2018) 2020 vision - An overview of prospects for diabetes management and prevention in the next decade. Diabetes Res Clin Pract 143: 101-112.

119. American Diabetes Association (2018) Classification and diagnosis of diabetes: Standards of medical care in Diabetes - 2018. Diabetes Care 41: S13-S27.

120. Bolen S, Feldman L, Vassy J, Wilson L, Yeh HC, et al. (2007). Systematic review: comparative effectiveness and safety of oral medications for type 2 diabetes mellitus. Ann Intern Med 147: 386-99.

121. Das A, Geetha KM, Hazarika I (2020) Contemporary updates on the physiology of glucagon like peptide- 1 and its agonist to treat type 2 diabetes mellitus. Int J Pept Res Ther 26: 1211-1221.

122. Ojo OO, Conlon JM, Flatt PR, Abdel-Wahab YHA (2013) Frog skin peptides (tigerinin-1R, magainin-AM1, -AM2, CPF-AM1, and PGla-AM1) stimulate secretion of glucagon-like peptide 1 (GLP-1) by GLUTag cells. Biochem Biophys Res Commun 431: 14-18.

123. Conlon JM, Mechkarska M, Lukic ML, Flatt PR (2014) Potential therapeutic applications of multifunctional host-defense peptides from frog skin as anti-cancer, anti-viral, immunomodulatory, and anti-diabetic agents. Peptides 57: 67-77.

124. Conlon JM, Mechkarska M, Abdel-Wahab YH, Flatt PR (2018) Peptides from frog skin with potential for development into agents for type 2 diabetes therapy. Peptides 100: 275-281. [Crossref]

125. Abdel-Wahab YHA, Power GJ, Ng MT, Flatt PR, Conlon JM (2008). Insulinreleasing properties of the frog skin peptide pseudin-2 and its [Lys18]-substituted analogue. Biol Chem 389: 143-148.

126. Ojo OO, Abdel-Wahab YHA, Flatt PR, Mechkarska M, Conlon JM (2011) Tigerinin-1R: a potent, non-toxic insulin-releasing peptide isolated from the skin of the Asian frog, Hoplobatrachus rugulosus. Diabetes Obes Metab 13: 1114-1122.

127. Srinivasan D, Mechkarska M, Abdel-Wahab YHA, Flatt PR, Conlon JM (2013) Caerulein precursor fragment (CPF) peptides from the skin secretions of Xenopus laevis and Silurana epitropicalis are potent insulin-releasing agents. Biochimie 95: 429-435.
128. Ojo OO, Srinivasan DK, Owolabi BO, Flatt PR, Abdel-Wahab YHA (2014) Magainin-related peptides stimulate insulin-release and improve glucose tolerance in high fat fed mice. Protein Pept Lett 22: 256-263.

129. Owolabi BO, Ojo OO, Srinivasan DK, Conlon JM, Flatt PR, et al. (2016) In vitro and in vivo insulinotropic properties of the multifunctional frog skin peptide hymenochirin-1B: a structure-activity study. Amino Acids 48: 535-547.

130. Vasu S, McGahon MK, Moffett RC, Curtis TM, Conlon JM, et al. (2017). Esculentin$2 \mathrm{CHa}(1-30)$ and its analogues: stability and mechanisms of insulinotropic action. $J$ Endocrinol 232: 423-435

131. Ojo OO, Srinivasan DK, Owolabi BO, Conlon JM, Flatt PR, et al. (2015) MagaininAM2 improves glucose homeostasis and beta cell function in high-fat fed mice. Biochim Biophys Acta 1850: 80-87.

132. Srinivasan D, Ojo OO, Owolabi BO, Conlon JM, Flatt PR, et al. (2015) The frog skin host-defense peptide CPF-SE1 improves glucose tolerance, insulin sensitivity and islet function and decreases plasma lipids in high-fat fed mice. Eur J Pharmacol 764: $38-47$.

133. Vasu S, Ojo OO, Moffett RC, Conlon JM, Flatt PR, Abdel-Wahab YHA (2017). Antidiabetic actions of esculentin-2 $\mathrm{CHa}(1-30)$ and its stable analogues in a diet-induced model of obesity-diabetes. Amino Acids 49: 1705-1717.

134. Lipsky BA, Holroyd KJ, Zasloff M (2008) Topical versus systemic antimicrobial therapy for treating mildly infected diabetic foot ulcers: a randomized, controlled, double-blinded, multicenter trial of pexiganan cream. Clin Infect Dis 47: 1537-1545.

135. Simon V, Ho DD, Abdool Karim Q (2006) HIV/AIDS epidemiology, pathogenesis, prevention, and treatment. Lancet 368: 489-504.

136. Yarchoan R, Uldrick TS (2018) HIV-associated cancers and related diseases. $N$ Engl J Med 378: 1029-1041. [Crossref]

137. UNAIDS (2019) Global HIV \& AIDS statistics - 2020 fact sheet. Downloaded from https://www.unaids.org/en/resources/fact-sheet. Accessed July 26, 2020.

138. Kallings LO (2008) The first postmodern pandemic: 25 years of HIV/AIDS. $J$ Intern Med 263: 218-243.

139. Sharp PM, Hahn BH (2011) Origins of HIV and the AIDS pandemic. CSH Perspect Med 1: a006841.

140. Gilbert PB, McKeague IW, Eisen G, Mullins C, Guéye-NDiaye A, et al. (2003) Comparison of HIV-1 and HIV-2 infectivity from a prospective cohort study in Senegal. Stat Med 22: 573-593.

141. Gallo RC (2006) A reflection on HIV/AIDS research after 25 years. Retrovirology 3: 72 .

142. Alimonti JB, Ball TB, Fowke KR (2003) Mechanisms of CD4+ T lymphocyte cell death in human immunodeficiency virus infection and AIDS. J Gen Virol 84: 1649 1661.

143. Luckheeram RV, Zhou R, Verma AD, Xia B (2012) CD4+ T cells: differentiation and functions. Clin Exp Immunol 2012: 925135.

144. May MT, Ingle SM (2011) Life expectancy of HIV-positive adults: a review. Sex Health 8: 526-533.

145. Iribarren JA, Rubio R, Aguirrebengoa K, Arribas JR, Baraia-Etxaburu J, et al. (2016) Prevention and treatment of opportunistic infections and other coinfections in HIVinfected patients: May 2015. Enferm Infecc Microbiol Clin 34: 516.e1-516.e18.

146. Lu DY, Wu HY, Yarla NS, Xu B, Ding J, et al. (2018) HAART in HIV/AIDS treatments: Future trends. Infect Disord Drug Targets 18: 15-22.

147. World Health Organization (2019) Update of recommendations on first- and secondline antiretroviral regimens. Downloaded from https://www.who.int/hiv/pub/arv/arvupdate-2019-policy/en/. Accessed July 7, 2020

148. Yasin B, Pang M, Turner JS, Cho Y, Dinh NN, et al. (2000) Evaluation of the inactivation of infectious herpes simplex virus by host-defense peptides. Eur J Clin Microbiol Infect Dis 19: 187-194.

149. Chinchar VG, Wang J, Murti G, Carey C, Rollins-Smith L (2001) Inactivation of frog virus 3 and channel catfish virus by esculentin-2P and ranatuerin-2P, two antimicrobial peptides isolated from frog skin. Virology 288: 351-357.

150. Savoia D, Donalisio M, Civra A, Salvadori S, Guerrini R (2010) In vitro activity of dermaseptin S1 derivatives against genital pathogens. APMIS 118: 674-680.

151. Belaid A, Aouni M, Khelifa R, Trabelsi A, Jemmali M, et al. (2002) In vitro antiviral activity of dermaseptins against herpes simplex virus type 1. J Med Virol 66: 229-234. 
152. Bergaoui I, Zairi A, Tangy F, Aouni M, Selmi B, et al. (2013) In vitro antiviral activity of dermaseptin $\mathrm{S}(4)$ and derivatives from amphibian skin against herpes simplex virus type 2. J Med Virol 85: 272-281.

153. Mechlia MB, Belaid A, Castel G, Jallet C, Mansfield KL, et al. (2019) Dermaseptins as potential antirabies compounds. Vaccine 37: 4694-4700.

154. Lorin C, Saidi H, Belaid A, Zairi A, Baleux F, et al (2005) The antimicrobial peptide dermaseptin S4 inhibits HIV-1 infectivity in vitro. Virology 334: 264-275.

155. Wang G, Watson KM, Peterkofsky A, Buckheit RW Jr (2010) Identification of novel human immunodeficiency virus type 1-inhibitory peptides based on the antimicrobial peptide database. Antimicrob Agents Chemother 54: 1343-1346. [Crossref]

156. Zhao Y, Jin Y, Wang JH, Wang RR, Yang LM, et al. (2005) A novel heme-containing protein with anti-HIV-1 activity from skin secretions of Bufo andrewsi. Toxicon 46: 619-624

157. Lai R, Zheng YT, Shen J-H, Liu GJ, Liu H, et al. (2002) Antimicrobial peptides from skin secretions of Chinese red belly toad Bombina maxima. Peptides 23: 427-435.

158. Mourão CBF, Schwartz EF (2013) Protease inhibitors from marine venomous animals and their counterparts in terrestrial venomous animals. Mar Drugs 11: 2069-2112.

159. Pokorná J, Machala L, Rezáčová P, Konvalinka J (2009) Current and novel inhibitors of HIV protease. Viruses 1: 1209-1239.

160. Lv Z, Chu Y, Wang Y (2015) HIV protease inhibitors: a review of molecular selectivity and toxicity. HIV AIDS (Auckl) 7: 95-104.

161. Weber IT, Kneller DW, Wong-Sam A (2015) Highly resistant HIV-1 proteases and strategies for their inhibition. Future Med Chem 7: 1023-1038.

162. Gao K-Q, Shubin NH (2012) Late Jurassic salamandroid from western Liaoning, China. Proc Natl Acad Sci USA 109: 5767-5772.

163. Marjanovic D, Laurin M (2014) An updated paleontological timetree of lissamphibians, with comments on the anatomy of Jurassic crown-group salamanders (Urodela). Hist Biol 26: 535-550.

164. Hanken J (1986) Small wonders. The Sciences 26: 40-43.

165. Sih A, Moore RD (1993) Delayed hatching of salamander eggs in response to enhanced larval predation risk. Am Nat 142: 947-960.

166. Brodie Jr ED (1978) Biting and vocalisation as antipredator mechanisms in terrestrial salamanders. Copeia 1: 127-129.

167. Brodie Jr ED, Nowak RT, Harvey WR (1979) Antipredator secretions and behavior of selected salamanders against shrews. Copeia 2: 270-274.

168. Beneski Jr JT (1989) Adaptive significance of tail autotomy in the salamander, Ensatina. J Herpetol 23: 322-324.

169. Lüddecke T, Schulz S, Steinfartz S, Vences M (2018) A salamander's toxic arsenal: review of skin poison diversity and function in true salamanders, genus Salamandra. Naturwissenschaften 105: 56.

170. Brodie Jr ED, Smatresk NJ (1990) The antipredator arsenal of fire salamanders: spraying of secretions from highly pressurized dorsal skin glands. Herpetologica 46 $1-7$.

171. Erjavec V, Lukanc B, Žel J (2017) Intoxication of a dog with alkaloids of the fire salamander. Med Weter 73: 186-188.

172. Vences M, Sanchez E, Hauswaldt SJ, Eikelmann D, Rodriguez A, et al. (2014) Nuclear and mitochondrial multilocus phylogeny and survey of alkaloid content in true salamanders of the genus Salamandra (Salamandridae). Mol Phyl Evol 73: 208216.

173. Crump M (2015) Eye of newt and toe of frog, adder's fork and lizard's leg: the lore and mythology of amphibians and reptiles. University of Chicago Press, Chicago (IL), USA.

174. He D, Zhu W, Zeng W, Lin J, Ji Y, Wang Y, et al. (2018) Nutritional and medicinal characteristics of Chinese giant salamander (Andrias davidianus) for applications in healthcare industry by artificial cultivation: A review. Food Sci Hum Well 7: 1-10.

175. Gang L, Baorong G, Ermi Z (2004) Andrias davidianus. The IUCN Red List of Threatened Species 2004: e.T1272A3375181.

176. Kozorog M (2003). Salamander brandy: 'a psychedelic drink' between media myth and practice of home alcohol distillation in Slovenia. Anthropol East Eur Rev 21: 63-71.
177. Hanifin CT, Yotsu-Yamashita Mari, Yasumoto T, Brodie ED, Brodie ED Jr (1999) Toxicity of dangerous prey: variation of tetrodotoxin levels within and among populations of the newt Taricha granulosa. J Chem Ecol 25: 2161-2175.

178. Chau R, Kalaitzis JA, Neilan BA (2011) On the origins and biosynthesis of tetrodotoxin. Aquat Toxicol 104: 61-72. [Crossref]

179. Lago J, Rodríguez LP, Blanco L, Vieites JM, Cabado AG (2015) Tetrodotoxin, an extremely potent marine neurotoxin: distribution, toxicity, origin and therapeutical uses. Mar Drugs 13: 6384-6406.

180. Brodie ED, Brodie ED Jr (1990) Tetrodotoxin resistance in garter snakes: an evolutionary response of predators to dangerous prey. Evolution 44: 651-659.

181. Moczydlowski EG (2013) The molecular mystique of tetrodotoxin. Toxicon 63: 165 183.

182. Noguchi T, Ebesu JSM (2001) Puffer poisoning: epidemiology and treatment. $J$ Toxicol Toxin Rev 20: 1-10.

183. Suehiro M (1996) Historical review of medical and chemical research on globefish toxin, tetrodotoxin. Revue D'histoire de la Pharmacie 44(suppl): 379-380.

184. Anderson PD (2012) Bioterrorism: toxins as weapons. J Pharm Pract 25: 121-129. doi: $10.1177 / 0897190012442351$.

185. Nieto FR, Cobos EJ, Tejada MÁ, Sánchez-Fernández C, González-Cano R, et al (2012) Tetrodotoxin (TTX) as a therapeutic agent for pain. Mar Drugs 10: 281-305.

186. Hagen NA, Fisher KM, Lapointe B, du Souich P, Chary S, et al. (2007) An openlabel, multi-dose efficacy and safety study of intramuscular tetrodotoxin in patients with severe cancer-related pain. J Pain Symptom Manag 34: 171-182.

187. Hagen NA, du Souich P, Lapointe B, Ong-Lam M, Dubuc B, et al. (2008) Tetrodotoxin for moderate to severe cancer pain: a randomized, double blind, paralle design multicenter study. J Pain Symptom Manag 35: 420-449.

188. Hagen NA, Lapointe B, Ong-Lam M, Dubuc B, Walde D, et al. (2011). A multicentre open-label safety and efficacy study of tetrodotoxin for cancer pain. Curr Oncol 18: e109-16.

189. Shi J, Liu TT, Wang X, Epstein DH, Zhao LY, et al. (2009) Tetrodotoxin reduces cueinduced drug craving and anxiety in abstinent heroin addicts. Pharmacol Biochem Behav 92: 603-607.

190. Song H, Li J, Lu C-L, Kang L, Xie L, et al. (2011) Tetrodotoxin alleviates acute heroin withdrawal syndrome: A multicentre, randomized, double-blind, placebocontrolled study. Clin Exp Pharmacol Physiol 38: 510-514.

191. Newman DJ, Cragg GM (2014) Marine-sourced anti-cancer and cancer pain control agents in clinical and late preclinical development. Mar Drugs 12: 255-278. [Crossref]

192. Adis International Ltd.C Springer Nature Switzerland AG. Tetrodotoxin WEX Pharmaceuticals. Downloaded from https://adisinsight.springer.com/ drugs/800016242. Accessed July 19, 2020

193. Zimmer T (2010) Effects of tetrodotoxin on the mammalian cardiovascular system. Mar Drugs 8: 741-762.

194. Berde CB, Athiraman U, Yahalom B, Zurakowski D, Corfas G, et al (2011) Tetrodotoxin-bupivacaine-epinephrine combinations for prolonged local anesthesia. Mar Drugs 9: 2717-2728.

195. Zaki ZA, Mady EA, Ahmed SM, Youssef NM (2001) Effect of tetrodotoxin (TTX) on some brain neurotransmitters in rats. J Nat Toxins 10: 307-316.

196. Habermehl G, Spiteller G (1967) Massenspektren der Salamander-Alkaloide [Mas spectrum of salamander alkaloid]. Eur J Org Chem 706: 213-222.

197. Daly JW, Garraffo HM, Spande TF (1999) Alkaloids from amphibian skins. In Pelletier SW (ed) Alkaloids: chemical and biological perspectives, vol 13, $1^{\text {st }}$ ed. Elsevier Science Ltd, Oxford, UK.

198. Mebs D, Pogoda W (2005) Variability of alkaloids in the skin secretion of the European fire salamander (Salamandra salamadra terrestris). Toxicon 45: 603-606.

199. Vences M, Sanchez E, Hauswaldt JS, Eikelmann D, Rodriguez A, et al. (2014) Nuclear and mitochondrial multilocus phylogeny and survey of alkaloid content in true salamanders of the genus Salamandra (Salamandridae). Mol Phylogenet Evol 73: 208-216.

200. Habermehl G, Preusser HJ (1969) Hemmung des Wachstums von Pilzen und Bakterien durch das Hautdrüsensekret von Salamandra maculosa [Inhibition of the growth of fungi and bacteria by the cutaneous gland secretion of Salamandra maculosa]. Z Naturforsch B 24: 1599-1601. 
201. Preusser HJ, Habermehl G, Sablofski M, Schmall-Haury D (1975) Antimicrobial activity of alkaloids from amphibian venoms and effects on the ultrastructure of yeast cells. Toxicon 13: 285-289

202. Karış M, Şener D, Yalçın HT, Nalbantsoy A, Göçmen B (2018) Major biological activities and protein profiles of skin secretions of Lissotriton vulgaris and Triturus ivanbureschi. Turkish J Biochem 43: 605-612.

203. Jenkins Jr FA, Walsh DM, Carroll RL (2007) Anatomy of Eocaecilia micropodia, a limbed caecilian of the Early Jurassic. Bull Mus Comp Zool 158: 285-365.

204. Wake MH (2005) The morphology of Idiocranium russeli (Amphibia: Gymnophiona), with comments on miniaturization through heterochrony. J Morphol 189: 1-16.

205. Arredondo J (2007) Caecilia thompsoni (Thompson's caecilian). Maximum body size. Herpetol Rev 38: 444-445.

206. Gower DJ, Wilkinson M (2002) Phallus morphology in caecilians (Amphibia, Gymnophiona) and its systematics utility. Bull Nat Hist Mus Zool 68: 143-154.

207. Gower DJ, Giri V, Dharne MS, Shouche YS (2008) Frequency of independent origins of viviparity among caecilians (Gymnophiona): evidence from the first 'live-bearing' Asian amphibian. J Evol Biol 21: 1220-1226.

208. Gomes AD, Moreira RG, Navas CA, Antoniazzi MM, Jared C (2012) Review of the reproductive biology of caecilians (Amphibia, Gymnophiona). South Am J Herpetol 7: 191-202.

209. Wilkinson M, Kupfer A, Marques-Porto R, Jeffkins H, Antoniazzi MM, et al. (2008) One hundred million years of skin feeding? Extended parental care in a neotropical caecilian (Amphibia: Gymnophiona). Biol Lett 4: 358-361. d

210. San Mauro D, Gower DJ, Oommen OV, Wilkinson M Zardoya R (2004) Phylogeny of caecilian amphibians (Gymnophiona) based on complete mitochondrial genomes and nuclear RAG1. Mol Phylogenet Evol 33: 413-427.

211. Zylberberg L, Wake MH (1990) Structure of the scales of Dermophis and Microcaecilia (Amphibia: Gymnophiona) and a comparison to dermal ossifications of other vertebrates. J Morphol 206: 25-43.

212. Jared C, Mailho-Fontana PL, Marques-Porto R, Sciani JM, Pimenta DC, et al. (2018) Skin gland concentrations adapted to different evolutionary pressures in the head and posterior regions of the caecilian Siphonops annulatus. Sci Rep 8: 3576.

213. Wollenberg KC, Measey GJ (2009) Why colour in subterranean vertebrates? Exploring the evolution of colour patterns in caecilian amphibians. J Evol Biol 22 1046-1056.

214. Breckenridge WR, Murugapillai R (1974) Mucous glands in the skin of Ichfhyophis glutinosus (Amphibia: Gymnophiona). Ceylon J Sci 11: 43-52.

215. Gabe M (1971) Donnees histologiques sur le tegument d'lchthyophis glutinosus L. (Batracien - Gymnophione) [Histological data on the integument of lchthyophis glutinosus L. (Batrachia - Gymnophiona). Ann Sci Nat Zoo Biol Anim 13: 573-607.
216. Moodie GEE (1978) Observations on the life history of the caecilian Typhlonectes compressicaudus (Dumeril and Bibron) in the Amazon basin. Can J Zool 56: 10051008 .

217. Schwartz EF, Schwartz CA, Sebben A, Mendes EG (1997) Cardiotoxic and hemolytic activities on the caecilian Siphonops paulensis skin secretion. J Venom Anim Toxins 3: 190

218. Schwartz EN, Schwartz CA, Sebben A (1998) Occurrence of hemolytic activity in the skin secretion of the caecilian Siphonops paulensis. Nat Toxins 6: 179-182.

219. Schwartz EN, Schwartz CA, Sebben A, Largura SW, Mendes EG (1999) Indirect cardiotoxic activity of the caecilian Siphonops paulensis (Gymnophiona, Amphibia) skin secretion. Toxicon 37: 47-54.

220. Schwartz EF, Stucchi-Zucchi A, Schwartz CA, Salomão LC (2003) Skin secretion of Siphonops paulensis (Gymnophiona, Amphibia) forms voltage-dependent ionic channels in lipid membranes. Braz J Med Biol Res 36: 1279-1282.

221. Pinto EG, Antoniazzi MM, Jared C, Tempone AG (2014) Antileishmanial and antitrypanosomal activity of the cutaneous secretion of Siphonops annulatus. Venom Anim Toxins Incl Trop Dis 20: 1-8.

222. Alves F, Bilbe G, Blesson S, Goyal V, Monnerat S, et al. (2018) Recent developmen of visceral leishmaniasis treatments: successes, pitfalls, and perspectives. Clin Microbiol Rev 31: e00048-18.

223. Pérez-Molina JA, Molina I (2018). Chagas disease. The Lancet 391: 82-94.

224. Sawaya P (1940) Sobre o veneno das glândulas cutâneas, a secreção e o coração de Siphonops annulatus [On the venom from the cutaneous glands, the secretion, and the heart of Siphonops annulatus]. Bol Fat Fil Ci Let Univ São Paulo Ser Zool 4 207-270

225. Ferroni EN, Schwartz CA, Sebben A, Mendes EG (1992) Ocorrência de serotonina (S-hidroxitriptamina) e bufotenina (NN-dimetil-5-hidroxitriptamina) em extrato de pele de Siphonops annulatus (Caeciliidae. Gymnophiona). Resumos do XIX Congresso Brasileiro de Zoologia. XII Congresso Latino-Americano de Zoologia, p. 120. Sot. Bras. 2001. Belém, Brazil.

226. Spande TF, Garraffo HM, Edwards MW, Yeh HJC, Pannell L, Daly JW (1992) Epibatidine: A novel (chloropyridyl)azabicycloheptane with potent analgesic activity from an Ecuadoran poison frog. J Am Chem Soc 114: 3475-3478.

227. Donnelly-Roberts DL, Puttfarcken PS, Kuntzweiler TA, Briggs CA, Anderson DJ, et al. (1998) ABT-594 [(R)-5-(2-Azetidinylmethoxy)-2-Chloropyridine]: a novel, orally effective analgesic acting via neuronal nicotinic acetylcholine receptors: I. in vitro characterization. J Pharmacol Exp Ther 285: 777-786.

228. Salehi B, Sestito S, Rapposelli S, Peron G, Calina D, et al. (2018) Epibatidine: a promising natural alkaloid in health. Biomolecules 9: 6. [Crossref]

229. González-Del-Pliego P, Freckleton RP, Edwards DP, Koo MS, Scheffers BR, et al. (2019) Phylogenetic and trait-based prediction of extinction risk for data-deficient amphibians. Curr Biol 29: 1557-1563.e3.

Copyright: (C2020 Mans DRA. This is an open-access article distributed under the terms of the Creative Commons Attribution License, which permits unrestricted use, distribution, and reproduction in any medium, provided the original author and source are credited. 